
\title{
25 Research Soure \\ Biofunctional significance of multi-herbal combination against paracetamol-induced hepatotoxicity in Wistar rats
}

\section{Pardeep Kaur}

Guru Nanak Dev University

Robin Shergill ( $\nabla$ robinbot.rsh@gndu.ac.in )

Guru Nanak Dev University and Khalsa College for Women, Amritsar https://orcid.org/0000-0001-67780740

\section{Rajendra G. Mehta}

IIT Research Institute and IIlinois Institute of Technology

\section{Balbir Singh ( $\square$ balbir_gndu@yahoo.com )}

Guru Nanak Dev University

\section{Saroj Arora ( $\nabla$ sarojarora.gndu@gmail.com )}

Guru Nanak Dev University

\section{Research Article}

Keywords: Drug-induced liver injury, Acetaminophen, HPLC, Hepatotoxicity, Multi-herbal combination, Wistar rats

Posted Date: June 18th, 2021

DOI: https://doi.org/10.21203/rs.3.rs-160477/v1

License: (c) (1) This work is licensed under a Creative Commons Attribution 4.0 International License. Read Full License 


\section{Abstract}

A multi-herbal combination (MHC) of five herbs, namely Punica granatum L., Putranjiva roxburghii Wall., Swertia chirata Buch.-Ham., Tinospora cordifolia (Willd.) Miers and Trigonella corniculata L., was assessed against the paracetamol-induced acute hepatotoxicity in female Wistar rats. The animals were randomly assorted into seven groups with six animals in each group. The rats were pre-treated with MHC $(50,100$, and $200 \mathrm{mg} / \mathrm{kg} \mathrm{bw})$ and silymarin $(50 \mathrm{mg} / \mathrm{kg} \mathrm{bw})$ once daily for seven consecutive days via oral route followed by administration of paracetamol $(3 \mathrm{~g} / \mathrm{kg} \mathrm{bw})$ on day 7 , an hour after the last administration of MHC and silymarin. It was observed that MHC administration significantly $(p \leq 0.05)$ overturned the paracetamol-induced increase in serum liver function biomarkers (serum glutamic oxaloacetic transaminase, serum glutamic pyruvic transaminase, alkaline phosphatase, and total bilirubin), phase I reaction enzymes (NADPH-cytochrome P450 reductase and NADH-cytochrome b5 reductase), and oxidant biomarkers (lactate dehydrogenase, lipid peroxidation, lipid hydroperoxides, and protein content). MHC administration also reinstated the paracetamol-induced significant decrease ( $p \leq$ 0.05 ) in haematological indices (haematocrit, haemoglobin, red and white blood cells, and platelets), phase II reaction enzymes (glutathione-S-transferase and DT-diaphorase), membrane-bound enzymes $\left(\mathrm{Na}^{+} / \mathrm{K}^{+}\right.$-ATPase, $\mathrm{Ca}^{2+}$-ATPase, and $\mathrm{Mg}^{2+}$-ATPase), and antioxidant biomarkers (reduced glutathione, superoxide dismutase, catalase, glutathione peroxidase, and glutathione reductase). Overall, $\mathrm{MHC}$ at 200 $\mathrm{mg} / \mathrm{kg}$ bw dose significantly $(p \leq 0.05)$ sheltered the red blood cells from the assault of free radicals, stabilized the structural and functional integrity of hepatocytes, hindered APAP biotransformation to its toxic metabolites, and endorsed conjugating abilities to detoxify toxic entities. Further, MHC significantly $(p \leq 0.05)$ activated enzymatic machinery to scavenge/inhibit the formation of reactive oxygen species, regulated nucleic acid metabolism, surface potential, and membrane fluidity, attenuated tissue breakdown, quenched peroxyl radicals, and provided protection against tissue injury. The necroinflammatory scores revealed strong evidence of MHC (200 mg/kg bw) effectiveness against the paracetamol-induced hepatotoxicity in rats at $p \leq 0.05$. The synergistic effect of major inherent phytoconstituents (kaempferol, ellagic acid, and gallic acid), detected by HPLC-PDA, in MHC might have overturned the paracetamol-induced biochemical toxic alterations in rat liver.

\section{Introduction}

At present time, a holistic therapeutic approach using botanicals is intensely required to underscore the complex cell biology coupled with multi-factorial pathogenesis. Concerning this, the notion of the pharmacological action of botanicals due to a single active principle or purified compound has now been substituted by the concept of the cumulative effect of several phytoconstituents (Carmona and Pereira 2013). This perspective engrosses the interaction between different plant-derived bioactive constituents and forms the basis of phytotherapy. Hence, phytotherapeutics protrudes as a multi-target strategy that encompasses combinatorial intervention of multiple bioactive constituents in the management of pathological conditions (Long et al. 2015). The core of phytotherapy is the diverse cluster of phytochemicals present in herbs, fruits, vegetables, green tea, cereals, legumes, and nuts which exhibit 
therapeutic or prophylactic action through their complex intervention. For example, polyphenols (a group of secondary metabolites), as a segment of this cluster, contribute to the prevention of many diseases at the cellular level and exert potential health benefits in humans (Tresserra-Rimbau et al. 2017). From a long-term perspective, pharmaceutical practices involving single active compound extraction models often lead to the resistance and failure of drug response under definite treatments of various ailments (Gnanaraj et al. 2017). Consequently, based on the folklore uses and beneficial health effects five plants i.e. Punica granatum L., Putranjiva roxburghii Wall., Swertia chirata Buch.-Ham., Tinospora cordifolia (Willd.) Miers, and Trigonella corniculata L. were scrutinized for the development of a multi-herbal combination (MHC) with biofunctional importance in antioxidative and antihepatoma studies, as discussed in our previous study (Kaur et al. 2019). For the MHC development, peel, leaves, whole herb, stems, and seeds of P. granatum, P. roxburghii, S. chirata, T. cordifolia, and T. corniculata were used, respectively. The study revealed that synergistic intervention of inherent phytoconstituents in $\mathrm{MHC}$ might have a multi-target prophylactic effect with better bioavailability due to effectual solubility in the aqueous medium. The study provided the evidence for anti-hepatocarcinoma action of MHC in HepG2 cells. However, the conventional two-dimensional (2D) planar cultures of HepG2 cells could presage capricious results which may cause inconsistent outcomes in normal hepatocytes (Kaur et al. 2018). The present study is the auxiliary investigation of MHC for its in vivo hepatoprotective significance against acetaminophen (APAP)-induced acute toxicity or drug-induced liver injury (DILI) in Wistar rats.

DILI may predispose to intrinsic and extrinsic environmental risk factors. The intrinsic implications are linked to the endogenous circadian rhythm, intestinal microbiome, hepatic clock, inflammation, and infection. Besides, extrinsic risk factors are associated with the regional geographic variation, socioeconomic status, environmental pollution, smoking, and alcohol consumption (Stine and Chalasani 2017). Amid these risks, alcohol consumption is a prime factor for paracetamol or APAP-induced hepatoxicity. APAP, a medication listed in the World Health Organization's list of essential medicines, is the most frequently used drug for the management of pain and fever (WHO 2019). For adolescents, of 50 $\mathrm{kg}$ or above weight, the U.S. Food and Drug Administration (FDA) recommended dosage of APAP is $1 \mathrm{~g}$ (Q6H: every 6 hours) or $0.65 \mathrm{~g}$ (Q4H: every 4 hours) restraining to a limit of $4 \mathrm{~g}$ per day (FDA 2015). Cases of acute liver failure linked with APAP overdose often result in liver transplantation or death. Many cases of acute liver injury associated with this drug frequently involve its presence in one or more OTC (over-thecounter) combination medications and prescribed medications. Several studies report that plant-based extracts and compounds with antioxidant and anti-inflammatory actions have a potential hepatoprotective effect and inhibit the biotransformation of APAP to its toxic metabolites (Abdel-Daim et al. 2018). Apropos to this, our newly developed MHC is assessed for its viability as a prospective formulation in in vivo hepatoprotective studies in Wistar rats against APAP-provoked acute hepatic dysfunction.

\section{Material And Methods}

\section{Chemicals and reagents}


APAP or N-(4-hydroxyphenyl)acetamide powder was procured from Sigma-Aldrich, Bangalore (India). All standard polyphenols with $\geq 90 \%$ purity for HPLC were procured from Sigma-Aldrich, Bangalore (India). For chromatographic analysis, HPLC-grade methanol and water were used. All other reagents and chemicals were of analytical grade.

\section{Preparation of MHC extract}

The disintegrated plant samples of $P$. granatum, P. roxburghii, S. chirata, T. cordifolia, and T. corniculata with a proportion of $33,27,25,10$, and $5 \%$ respectively, were soaked mutually and decoction was prepared as described in our previous study (Kaur et al. 2019). The filtered decoction was dried on a water bath and the extract was used for further experiments. The acquaintances of five herbs in this multiherbal combination (MHC) were based on three essential points. The first point was the identification of prominent or primary herb(s), the second was the identification of the nourisher herb(s) and the third point was the categorization of active stimulator herb(s) (Fig. 1).

\section{High-performance liquid chromatography-photo diode array (HPLC-PDA) analysis}

HPLC-PDA analysis of MHC extract was performed on Nexera UHPLC (Shimadzu, Kyoto, Japan) as per the standardized procedure in our previous publication (Kaur et al. 2019). The Enable C-18 G (150 × 4.6 $\mathrm{mm}, 5 \mu \mathrm{m}$ particle size) column was used at $25^{\circ} \mathrm{C}$ column oven temperature. The photo diode array detector was used with a $280 \mathrm{~nm}$ detection wavelength. The elution system (low-pressure gradient) with $0.1 \%$ acetic acid in water $(A)$ and methanol (B) mobile phase were used. The flow rate was $1 \mathrm{ml} / \mathrm{min}$ with an injection volume of $5 \mu \mathrm{l}$. The gradient program started at $30 \% \mathrm{~B}$ to $45 \% \mathrm{~B}$ in $12 \mathrm{~min}, 45-75 \% \mathrm{~B}$ in 13.5 min, maintaining 75\% B until 15 min, 75-50\% B in 16.6 min, 50-25\% B in 18 min, upholding 25\% B until $20 \mathrm{~min}, 25-30 \%$ B in $21 \mathrm{~min}$ and stopped at $22 \mathrm{~min}$ with sustained elution until $26 \mathrm{~min}$.

\section{Animal care and handling}

Healthy female Wistar rats weighing 150-200 g (6-8 weeks old) used in the present study were procured from the National Institute of Pharmaceutical Education and Research (NIPER), Mohali, Punjab (India). The rats were housed in the Central Animal House of Guru Nanak Dev University, Amritsar under hygienic conditions in polypropylene cages employing paddy husk bedding (changed regularly) at a temperature of $25 \pm 2^{\circ} \mathrm{C}$ with a 12-hour light / 12-hour dark cycle. The animals were fed on a standard pellet diet and had tap water ad libitum throughout treatment. The animals for the experimental purpose were allowed to acclimatize for two weeks prior to the commencement of the treatment schedule.

\section{Experimental design}

The animals were randomly assorted into seven groups (Group I-VII) with six animals in each group ( $n=$ 6). The rats were pre-treated with $\mathrm{MHC}$ and silymarin once daily for 7 consecutive days followed by administration of paracetamol on the 7th day an hour after the last dose of the respective drug was given. Hepatotoxicity was induced by a single toxic dose of paracetamol ( $3 \mathrm{~g} / \mathrm{kg} \mathrm{bw})$ suspended in distilled water as reported previously by Madkour and Abdel-Daim (2013). The different concentrations of 
$\mathrm{MHC}$ and standard silymarin were administered as per body weight (bw) and the doses were given to animals via oral route using a canula (Table 1).

Table 1

The experimental design and animal grouping

\begin{tabular}{|c|c|c|c|c|c|c|}
\hline \multicolumn{7}{|c|}{ Treatment groups: Female Wistar rats $(n=6)$} \\
\hline I & II & III & IV & V & VI & VII \\
\hline \multicolumn{7}{|c|}{ Dose administration via p.o. route } \\
\hline Day 1-7 & Day 7 & \multicolumn{5}{|c|}{ For seven consecutive days } \\
\hline \multirow{4}{*}{$\begin{array}{l}\text { Standard pellet diet } \\
\text { and tap water ad } \\
\text { libitum } \\
\text { (Untreated control) }\end{array}$} & \multirow{4}{*}{$\begin{array}{l}\text { Paracetamol } \\
(3 \mathrm{~g} / \mathrm{kg} \mathrm{bw})\end{array}$} & \multirow{4}{*}{$\begin{array}{l}\text { MHC } \\
(200 \\
\mathrm{mg} / \mathrm{kg} \\
\mathrm{bw}) \text { per } \\
\text { se }\end{array}$} & $\mathrm{MHC}$ & $\mathrm{MHC}$ & $\mathrm{MHC}$ & Silymarin \\
\hline & & & $(50$ & $(100$ & $(200$ & (50 \\
\hline & & & $\begin{array}{l}\mathrm{mg} / \mathrm{kg} \\
\mathrm{bw})\end{array}$ & $\begin{array}{l}\mathrm{mg} / \mathrm{kg} \\
\mathrm{bw})\end{array}$ & $\begin{array}{l}\mathrm{mg} / \mathrm{kg} \\
\mathrm{bw})\end{array}$ & $\begin{array}{l}\mathrm{mg} / \mathrm{kg} \\
\mathrm{bw})\end{array}$ \\
\hline & & & \multicolumn{4}{|c|}{$\begin{array}{l}\text { Paracetamol }(3 \mathrm{~g} / \mathrm{kg} \mathrm{bw}) \text { on day } 7 \text {, an hour } \\
\text { after the last administration of MHC and } \\
\text { silymarin }\end{array}$} \\
\hline
\end{tabular}

Group I: Normal control included the animals that were put on a normal pellet diet. Group II: Paracetamol $(3 \mathrm{~g} / \mathrm{kg} \mathrm{bw})$ in which animals received a single high dose of paracetamol on the 7th day to assess the severity of acute hepatic damage. Group III: MHC $(200 \mathrm{mg} / \mathrm{kg} \mathrm{bw})$ per se included rats which were administered with the high dose of $\mathrm{MHC}$ once daily for seven days to ensure that it did not provoke any sort of toxicity itself. The animals of Group IV: MHC ( $50 \mathrm{mg} / \mathrm{kg} \mathrm{bw})+$ Paracetamol, Group V: MHC (100 $\mathrm{mg} / \mathrm{kg}$ bw) + Paracetamol, and Group Vl: MHC (200 mg/kg bw) + Paracetamol received low, mid, and high doses of MHC respectively for seven days and were intoxicated with paracetamol an hour after the administration of the last dose of combination on the 7th day. Group VIl: Silymarin ( $50 \mathrm{mg} / \mathrm{kg} \mathrm{bw})+$ Paracetamol in which animals were treated with the aqueous suspension of silymarin once daily for seven days followed by a single oral dose of paracetamol on the 7th day. The choice of dose of silymarin was based on a previous study in the literature (Paul et al. 2016).

\section{Estimation of haematological indices}

Blood samples were withdrawn from the rats in the above stated seven groups $48 \mathrm{~h}$ post-administration of paracetamol. The samples were collected by puncturing the retro-orbital venous plexus with sterilized capillary under light diethyl ether anaesthesia into EDTA coated vacutainers for determination of haematological parameters (haematocrit, haemoglobin concentration, red blood cells (RBCs), white blood cells (WBCs), and platelet count) using Automated Haematology Cell Counter.

\section{Estimation of serum liver function biomarkers}


For serum biochemical assessment blood samples were collected in clot activator vacutainers and samples were kept for $20 \mathrm{~min}$ at room temperature followed by centrifugation of the coagulated blood at $3000 \mathrm{rpm}$ for $10 \mathrm{~min}$. The clear supernatant designated as the serum was kept at $-80^{\circ} \mathrm{C}$ until analysed (Kale et al. 2012). The biomarkers of hepatic injury viz., serum glutamic oxaloacetic transaminase (SGOT), serum glutamic pyruvic transaminase (SGPT), serum alkaline phosphatase (ALP), and total bilirubin were estimated by means of Erba Mannheim XL-640 Autoanalyzer using Erba Mannheim XL SYSPACK kits.

\section{Preparation of liver homogenate}

Following blood collection, the rats were sacrificed by cervical dislocation and the livers of animals were perfused instantly with ice-cold sodium chloride $(0.9 \%)$, isolated carefully, trimmed free of any adhering fat and other extraneous tissues. The organs were then suspended and rinsed in chilled $0.15 \mathrm{M}$ Tris- $\mathrm{KCl}$ buffer $(\mathrm{pH} 7.4)$ consisting of potassium chloride $(0.15 \mathrm{M})$ and tris-hydrochloride $(10 \mathrm{mM})$. Thereafter, liver samples were blotted dry, weighed immediately, and homogenized by means of a glass Teflon homogenizer in a buffer to yield $10 \%(\mathrm{w} / \mathrm{v})$ liver homogenate. To $500 \mu \mathrm{L}$ of this homogenate trichloroacetic acid (5\%) was added following centrifugation at $2000 \mathrm{rpm}$ to allow sedimentation of tissue debris and the supernatant was utilized to determine the content of reduced glutathione. The remaining homogenate was centrifuged for $20 \mathrm{~min}$ at 10,000 rpm and supernatant thus obtained, after disposing of unbroken cells, any floating lipid layer, cell debris, was used for the assessment of different enzymes such as phase-I, phase-II, antioxidant and membrane-bound enzymes (Kaur and Arora 2013).

\section{Estimation of phase-I reaction enzymes}

\section{NADPH-cytochrome P450 reductase (CPR)}

The activity of CPR was determined based on the rate of oxidation of nicotinamide adenine dinucleotide phosphate (NADPH) and reduction of potassium ferricyanide as reported by Omura and Takesue (1970). The specific activity was expressed in terms of IU/mg protein. Here, IU signifies $\mu \mathrm{M}$ NADPH oxidised $/ \mathrm{min} / \mathrm{mg}$ protein content.

$$
\text { Specificactivity }=\frac{\text { Changeinabsorbance } \times \text { Totalreactionvolume } \times \text { dilution }}{\text { Extinctioncoefficient } \times \text { Proteincontent }}
$$

\section{NADH-cytochrome b5 reductase (b5R)}

The specific activity of b5R based on the rate of oxidation of nicotinamide adenine dinucleotide hydride (NADH) was estimated as per the method outlined by Mihara and Sato (1972). The specific activity of b5R was expressed in terms of IU/mg protein. Here, IU signifies $\mu \mathrm{M}$ ferricyanide reduced $/ \mathrm{min} / \mathrm{mg}$ protein content.

$$
\text { Specificactivity }=\frac{\text { Changeinabsorbance } \times \text { Totalreactionvolume } \times \text { dilution }}{\text { Extinctioncoefficient } \times \text { Proteincontent }}
$$




\section{Estimation of phase-II reaction enzymes}

\section{Glutathione-S-transferase (GST)}

The enzymatic activity of GST, to detoxify the xenobiotics, was determined as described by Habig et al. (1974) and expressed in terms of IU/mg protein. Here, IU signifies $\mu \mathrm{M}$ glutathione-CDNB (1-Chloro-2,4dinitrobenzene) conjugate formed $/ \mathrm{min} / \mathrm{mg}$ protein content.

$$
\begin{gathered}
\text { Unitactivity }=\frac{\text { Changeinabsorbance } / \text { minute } \times \text { Totalreactionvolume }}{\text { Extinctioncoefficient } \times \text { Volumeofhomogenateused }} \\
\text { Specificactivity }=\frac{\text { Unitactivity }}{\text { Proteincontent }}
\end{gathered}
$$

\section{DT-diaphorase (DTD)}

NAD(P)H quinone oxidoreductase 1 (DTD) was assayed adopting the methodology of Ernster (1967) in which NADH is used as an electron donor, 2,6-dichlorophenolindophenol (DCPIP) as an electron acceptor, and bovine serum albumin (BSA) as an activator. The values were expressed as IU/mg protein. This assay engrosses oxidation of NADH and reduction of DCPIP catalysed by DTD. Thus, here IU signifies $\mu$ M DCPIP reduced $/ \mathrm{min} / \mathrm{mg}$ protein content.

$$
\begin{gathered}
\text { Unitactivity }=\frac{\text { Changeinabsorbance } / \text { minute } \times \text { Totalreactionvolume }}{\text { Extinctioncoefficient } \times \text { Volumeofhomogenateused }} \\
\text { Specificactivity }=\frac{\text { Unitactivity }}{\text { Proteincontent }}
\end{gathered}
$$

\section{Estimation of membrane-bound enzymes}

\section{$\mathrm{Na}^{+} / \mathrm{K}^{+}$-ATPase}

The $\mathrm{Na}^{+} / \mathrm{K}^{+}$-ATPase enzyme pumps out $\mathrm{Na}^{+}$and $\mathrm{K}^{+}$into cells against the concentration gradient using energy from adenosine triphosphate (ATP) and is measured by the release of inorganic phosphorous. The assay was performed as per the methodology given by Bonting (1970). The assessment of phosphorous content was carried out as per the procedure described by Fiske and Subbarow (1925). The enzymatic activity was expressed as $\mu \mathrm{M}$ phosphorous liberated $/ \mathrm{min} / \mathrm{mg}$ protein.

\section{$\mathrm{Ca}^{2+}$-ATPase}

The methodology of Hjerten and Pan (1983) was followed for the determination of $\mathrm{Ca}^{2+}$-ATPase activity. The amount of phosphorous liberated from the substrate was assessed as per the method described by Fiske and Subbarow (1925). The enzyme activity was expressed in terms of $\mu \mathrm{M}$ phosphorous liberated/min/mg protein. 


\section{$\mathrm{Mg}^{2+}$-ATPase}

The $\mathrm{Mg}^{2+}$-ATPase enzyme activity was assayed by the method prescribed by Ohnishi et al. (1982) and phosphorous content was estimated by following the protocol of Fiske and Subbarow (1925). The results of enzyme activity were expressed as $\mu \mathrm{M}$ phosphorous liberated/min/mg protein.

\section{Estimation of oxidant/antioxidant biomarkers}

\section{Oxidant biomarkers}

Lactate dehydrogenase (LDH) - The methodology of Kuznetsov and Gnaiger (2010) was followed to evaluate the rate of oxidation of pyruvate by $\mathrm{NADH}$, determining the enzymatic activity of LDH. The results of specific activity were expressed as IU/mg protein where IU represents $\mu \mathrm{M} N A D H$ reduced $/ \mathrm{min} / \mathrm{mg}$ protein content.

$$
\begin{gathered}
\text { Unitactivity }=\frac{\text { Changeinabsorbance } / \text { minute } \times \text { Totalreactionvolume }}{\text { Extinctioncoefficient } \times \text { Volumeofhomogenateused }} \\
\text { Specificactivity }=\frac{\text { Unitactivity }}{\text { Proteincontent }}
\end{gathered}
$$

\section{Lipid peroxidation (LPO)}

LPO was determined as per the method described by Devasagayam et al. (2003) in terms of the formation of characteristic pink-coloured thiobarbituric acid reactive substances (TBARS) and the absorbance was measured at $532 \mathrm{~nm}$ using an ELISA microplate reader (Synergy HT, BioTek). The results were expressed as $\mu \mathrm{M}$ malondialdehyde (MDA) equivalent/g tissue calculated from the calibration curve obtained using MDA as a standard.

\section{Lipid hydroperoxide}

The content of lipid peroxides was calculated from the regression equation obtained by using hydrogen peroxide as standard and values were expressed as $\mathrm{mM} \mathrm{H}_{2} \mathrm{O}_{2}$ equivalent/g tissue. This method involves the oxidation of ferrous ions to ferric ions in an acidic environment. Ferric ions then form a complex with xylenol orange which is measured at $560 \mathrm{~nm}$ (Jiang et al. 1992).

\section{Protein content}

The protein content in tissue homogenate was estimated using the procedure given by Smith et al. (1985) in which sodium salt of bicinchoninic acid forms a purple complex with cuprous ions under alkaline conditions. BSA was used as a standard to draw the regression equation and to determine the protein content in terms of $\mathrm{mg} / \mathrm{g}$ tissue.

\section{Antioxidant biomarkers}




\section{Reduced glutathione(GSH)}

The content of GSH in liver tissues was assessed by its reaction with 5,5'-dithiobis-(2-nitrobenzoic acid) (DTNB) following the methodology of Anderson (1985). The glutathione content was calculated in terms of $\mathrm{mM} \mathrm{SH}$ content/g tissue from the regression equation obtained by using $\mathrm{GSH}$ as a standard.

Superoxide dismutase (SOD) - The activity of SOD was assayed following the method proposed by Kono (1978) based on the ability of the enzyme to inhibit the reduction of nitroblue tetrazolium (NBT) accompanying autoxidation of hydroxylamine. Specific activity of the enzyme was expressed as IU/mg protein. IU indicates units of SOD enzyme/min/mg protein.

Percent inhibition:

Changeinabsorbance/ minute(Blank) - Changeinabsorbance/minute(Sample) Changeinabsorbance/ minute(Blank) $\times 100=x$

Where,

$x=\%$ inhibition of NBT reduction by $70 \mu \mathrm{L}$ of homogenate

$$
\begin{gathered}
\text { SODenzymein70 } \mu \text { Lofhomogenate }=\frac{1}{50} \times x=\text { yunit } \\
\text { Unitactivity }=\frac{y}{70} \times 1000 \\
\text { Specificactivity }=\frac{\text { Unitactivity }}{\text { Proteincontent }}
\end{gathered}
$$

Catalase (CAT) - CAT was analyzed on the basis of the rate of disappearance of hydrogen peroxide at $240 \mathrm{~nm}$ as per the method given by Aebi (1984). The specific activity of CAT was expressed as IU/mg protein. Here, IU indicates the $\mu \mathrm{M}$ hydrogen peroxide decomposed $/ \mathrm{min} / \mathrm{mg}$ protein content.

$$
\begin{gathered}
\text { Unitactivity }=\frac{\text { Changeinabsorbance } / \text { minute } \times \text { Totalreactionvolume }}{\text { Extinctioncoefficient } \times \text { Volumeofhomogenateused }} \\
\text { Specificactivity }=\frac{\text { Unitactivity }}{\text { Proteincontent }}
\end{gathered}
$$

Glutathione peroxidase (GPx) - GPx was assayed according to the procedure described by Paglia and Valentine (1967) which involves indirect measurement of its activity. The specific activity was expressed in terms of IU/mg protein. IU signifies $\mu \mathrm{M}$ NADPH oxidized $/ \mathrm{min} / \mathrm{mg}$ protein content.

$$
\text { Unitactivity }=\frac{\text { Changeinabsorbance } / \text { minute } \times \text { Totalreactionvolume }}{\text { Extinctioncoefficient } \times \text { Volumeofhomogenateused }}
$$




$$
\text { Specificactivity }=\frac{\text { Unitactivity }}{\text { Proteincontent }}
$$

Glutathione reductase (GR) - The protocol of Carlberg and Mannervik (1985) was followed to determine the activity of GR based on the amount of NADPH consumed in the conversion of oxidized glutathione to reduced glutathione. The results were expressed as IU/mg protein. Here, IU represents $\mu$ M NADPH oxidised/min/mg protein content.

$$
\begin{gathered}
\text { Unitactivity }=\frac{\text { Changeinabsorbance } / \text { minute } \times \text { Totalreactionvolume }}{\text { Extinctioncoefficient } \times \text { Volumeofhomogenateused }} \\
\text { Specificactivity }=\frac{\text { Unitactivity }}{\text { Proteincontent }}
\end{gathered}
$$

\section{Histopathological examination of liver}

The livers from each of the six animals of all experimental groups were excised and preserved in formalin $(10 \%)$ solution. Then liver specimens were processed, embedded in paraffin blocks, and $3-4 \mu \mathrm{m}$ thick sections were prepared followed by staining with haematoxylin and eosin in compliance with the standard techniques. Liver sections were coded and then observed microscopically for pathological findings such as coagulative necrosis, apoptosis, and portal triad inflammation by the pathologist. Ishak modified histological index grading (HAl) was used to score and evaluate liver damage (Ishak et al. 1995).

\section{Statistical analysis}

The resultant data of six animals were presented as mean \pm standard error (SE). The statistical differences among mean data were assessed by one-way analysis of variance (ANOVA) at a $5 \%$ level of significance i.e. $p \leq 0.05$. Post hoc Tukey's HSD was performed at $p \leq 0.05$ and statistical pairwise comparisons were presented by lowercase letters displayed on bar graphs. The Kruskal-Wallis $\mathrm{H}$ test with Dunn-Bonferroni post hoc was performed at $p \leq 0.05$ to test the significant differences between seven treatment groups (Group I-VII) of independent variables on ordinal dependent variables i.e. scores of Ishak modified HAI necroinflammatory grading.

\section{Results}

\section{HPLC-PDA analysis}

The HPLC chromatogram revealed the presence of major polyphenolic compounds as shown in Fig. 2. It was observed that the highest amount of kaempferol $(40.68 \mu \mathrm{g} / \mathrm{mg})$ was detected in MHC followed by ellagic acid, gallic acid, quercetin, and epicatechin.

In vivo hepatoprotective studies

\section{Percentage change in body weight}


The percentage change in body weight of Wistar rats was observed at the termination of the experiment as shown in Fig. 3. It was found that the highest body weight change (8.718\%) was observed in rats pretreated with $200 \mathrm{mg} / \mathrm{kg}$ bw dose of $\mathrm{MHC}$ while the minimum body weight change (5.481\%) was seen in paracetamol intoxicated animals. No statistical difference was observed at a $5 \%$ level of significance on comparing the normal and paracetamol intoxicated group. Furthermore, pre-treatment with $\mathrm{MHC}$ at all the three tested doses $(50,100$, and $200 \mathrm{mg} / \mathrm{kg}$ bw), silymarin ( $50 \mathrm{mg} / \mathrm{kg} \mathrm{bw})$, and MHC (200 mg/kg bw) per se also revealed no significant difference in comparison to normal control at $p \leq 0.05$. Supplementary data are given in Table S1.

\section{Haematological indices}

\section{Haematocrit}

Hepatic injury incited by paracetamol caused a significant decrease $(p \leq 0.05)$ in haematocrit $(35.70 \%)$ as compared to untreated control (44.52\%). However, administration of MHC resulted in a significant increase in the percentage of haematocrit in a dose-responsive manner, i.e. $39.23,42.65$, and $45.03 \%$ at doses of 50,100 , and $200 \mathrm{mg} / \mathrm{kg}$ bw, respectively (Fig. 4a). It was also noticed that the highest dose of $\mathrm{MHC}$ restored the parameter to the normal range with no statistically significant difference at $p \leq 0.05$. Silymarin (50 mg/kg bw) used as a standard in the present study showed a value of $42.63 \%$ while MHC per se displayed $41.42 \%$. The feeding of animals with MHC $(200 \mathrm{mg} / \mathrm{kg} \mathrm{bw})$ per se did not reveal any significant sign of toxicity. Supplementary data are given in Table S2.

\section{Haemoglobin}

The protective effect of pre-treatment of MHC and silymarin on paracetamol-induced alterations in haemoglobin content is presented in Fig. 4b. Intoxication of hepatotoxin at $3 \mathrm{~g} / \mathrm{kg}$ bw dose to the rats caused a significant reduction $(p \leq 0.05)$ in haemoglobin $(8.567 \mathrm{~g} / \mathrm{dL})$ when compared with normal control $(12.70 \mathrm{~g} / \mathrm{dL})$. Regarding MHC, regulation in haemoglobin was observed with values of 10.63 , 11.20 , and $12.33 \mathrm{~g} / \mathrm{dL}$ at the doses of 50,100 , and $200 \mathrm{mg} / \mathrm{kg}$ bw respectively. Silymarin preadministration showed a value of $12.40 \mathrm{~g} / \mathrm{dL}$. Both the highest dose of $\mathrm{MHC}$ and silymarin reflected statistical similarity at a $5 \%$ level of significance. Also, $200 \mathrm{mg} / \mathrm{kg}$ bw dose of MHC per se demonstrated the value of $11.55 \mathrm{~g} / \mathrm{dL}$ and had no significant toxic effect on haemoglobin content. Supplementary data are given in Table $\mathrm{S} 2$.

\section{Total RBCs count}

The effect of paracetamol intoxication as well as pre-treatment of $\mathrm{MHC}$ and silymarin on total RBCs count is presented in Fig. 4c. Group II animals that were given a toxic dose ( $3 \mathrm{~g} / \mathrm{kg} \mathrm{bw})$ of paracetamol showed a marked decrease $(p \leq 0.05)$ in total RBCs count $\left(3.225 \times 10^{12} / \mathrm{L}\right)$ in comparison to normal group animals $\left(4.898 \times 10^{12} / \mathrm{L}\right)$. Pre-administration of $\mathrm{MHC}$ at 50,100 , and $200 \mathrm{mg} / \mathrm{kg}$ bw showed dosedependent increase in values i.e. $4.670 \times 10^{12} / \mathrm{L}, 4.812 \times 10^{12} / \mathrm{L}$, and $4.983 \times 10^{12} / \mathrm{L}$ respectively. Silymarin administration ( $50 \mathrm{mg} / \mathrm{kg}$ bw) displayed the total RBCs count of $4.767 \times 10^{12} / \mathrm{L}$. However, 
group comparison revealed no significant difference among the groups pre-treated with the three doses of MHC and silymarin. In addition, the total RBCs count was observed to be $4.952 \times 10^{12} / \mathrm{L}$ in rats administered with MHC (200 mg/kg bw) per se reflecting no significant difference at $p \leq 0.05$ in comparison to untreated control. Supplementary data are given in Table S2.

\section{Total WBCs count}

The protective effect of MHC and silymarin pre-treatment on total WBCs count against paracetamol intoxication is presented in Fig. 4d. Group II animals that were challenged with a toxic dose of paracetamol $(3 \mathrm{~g} / \mathrm{kg} \mathrm{bw})$ showed a marked decrease $(p \leq 0.05)$ in total WBCs count $\left(3.430 \times 10^{9} / \mathrm{L}\right)$ in comparison to normal group animals $\left(6.627 \times 10^{9} / \mathrm{L}\right)$. Pre-treatment with $\mathrm{MHC}$ at 50,100 , and $200 \mathrm{mg} / \mathrm{kg}$ bw doses showed the values $6.478 \times 10^{9} / \mathrm{L}, 6.522 \times 10^{9} / \mathrm{L}$, and $6.688 \times 10^{9} / \mathrm{L}$ respectively. Also, silymarin pre-administration displayed the total WBCs count of $6.828 \times 10^{9} / \mathrm{L}$. However, group comparison among the three tested doses of $\mathrm{MHC}$ and silymarin revealed no significant difference at $p \leq 0.05$. In addition, the total WBCs count was observed to be $6.432 \times 10^{9} / \mathrm{L}$ in animals administered with MHC at $200 \mathrm{mg} / \mathrm{kg}$ bw dose per se indicating no apparent sign of toxicity. Supplementary data are given in Table S2.

\section{Platelet count}

The toxic effect of paracetamol intoxication as well protective response of $\mathrm{MHC}$ and silymarin pretreatment on platelet count is presented in Fig. 4e. Animals that were intoxicated with paracetamol showed a significant decrease $(p \leq 0.05)$ in platelet count $\left(134.5 \times 10^{9} / \mathrm{L}\right)$ in comparison to the normal group $\left(327 \times 10^{9} / \mathrm{L}\right)$. However, MHC at 50, 100, and $200 \mathrm{mg} / \mathrm{kg}$ bw dose administration showed the values $332.9 \times 10^{9} / \mathrm{L}, 335.2 \times 10^{9} / \mathrm{L}$, and $352.3 \times 10^{9} / \mathrm{L}$ respectively. Pre-treatment with silymarin displayed a platelet count of $335.8 \times 10^{9} / \mathrm{L}$. Group comparison revealed no significant difference among the groups that were given 50,100 , and $200 \mathrm{mg} / \mathrm{kg}$ bw dose of $\mathrm{MHC}$ and $50 \mathrm{mg} / \mathrm{kg}$ bw dose of silymarin. In addition, platelet count was observed to be $359 \times 10^{9} / \mathrm{L}$ in rats administered with $\mathrm{MHC}(200 \mathrm{mg} / \mathrm{kg} \mathrm{bw})$ per se indicating no apparent sign of toxicity. Supplementary data are given in Table S2.

\section{Serum liver function biomarkers}

\section{Serum glutamic oxaloacetic transaminase (SGOT)}

The level of SGOT was seen to be $785 \mathrm{IU} / \mathrm{L}$ in paracetamol intoxicated animals, which was observed to be significantly higher $(p \leq 0.05)$ than that of control $(106.3 \mathrm{IU} / \mathrm{L})$. This induction in serum level was diminished dose-dependently by oral pre-treatment of MHC. As seen from Fig. $5 \mathrm{a}$, values were 447.2, 267.8 , and $175.4 \mathrm{IU} / \mathrm{L}$ in groups administered with 50,100 , and $200 \mathrm{mg} / \mathrm{kg}$ bw doses of MHC respectively. The value of $98.27 \mathrm{IU} / \mathrm{L}$ in animals that were given $200 \mathrm{mg} / \mathrm{kg}$ bw dose of MHC indicated that the combination by itself did not show any toxicity and no significant difference in comparison to the control group was observed. Similarly, silymarin pre-treatment also reduced the elevated level of SGOT to $147.8 \mathrm{IU} / \mathrm{L}$. Further, the highest dose of MHC (200 mg/kg bw) and silymarin (50 mg/kg bw) reflected the 
potential to counteract the toxic effects of paracetamol with no statistical difference at a $5 \%$ level of significance. Supplementary data are given in Table S3.

\section{Serum glutamic pyruvic transaminase (SGPT)}

The biochemical investigation of serum revealed a prominent elevation $(p \leq 0.05)$ in SGPT level in animals administered with a $3 \mathrm{~g} / \mathrm{kg}$ bw dose of paracetamol as compared to the normal group. The values were observed to be $128.6 \mathrm{IU} / \mathrm{L}$ and $32.39 \mathrm{IU} / \mathrm{L}$ in the paracetamol and normal group respectively. The results presented in Fig. $5 \mathrm{~b}$ indicated that rats administered with $\mathrm{MHC}$ for seven consecutive days reduced the elevated level to $84.43,55.03$, and $37.46 \mathrm{IU} / \mathrm{L}$ in a dose-responsive manner while in the silymarin treated group, the value was observed to be $30.43 \mathrm{IU} / \mathrm{L}$. It was elucidated that values exhibited by $200 \mathrm{mg} / \mathrm{kg}$ bw dose of $\mathrm{MHC}$ and $50 \mathrm{mg} / \mathrm{kg}$ bw dose of silymarin were statistically similar $(p \leq 0.05)$ to the basal value as seen in the control group. In addition, MHC per se showed the value $37.61 \mathrm{IU} / \mathrm{L}$ and did not produce any significant change in the parameter studied in comparison to control. Supplementary data are given in Table S3.

Alkaline phosphatase (ALP): In the present study, it was observed that level of ALP was significantly augmented $(p \leq 0.05)$ in animals receiving paracetamol $(838.0 \mathrm{IU} / \mathrm{L})$ than the control group $(276.2 \mathrm{IU} / \mathrm{L})$. However, pre-treatment of $\mathrm{MHC}$ at 50,100 , and $200 \mathrm{mg} / \mathrm{kg}$ bw for seven consecutive days significantly influenced the toxic effects by reducing the values in a dose-dependent way (Fig. 5c). The values were observed to be $551.6,364.4$, and $274.7 \mathrm{IU} / \mathrm{L}$ at 50,100 , and $200 \mathrm{mg} / \mathrm{kg}$ bw dose respectively. A significant suppression (184.3 IU/L) at a $5 \%$ level was also seen in the silymarin-treated group in comparison to the paracetamol intoxicated group. Also, the value exhibited by MHC per se $(208.4 \mathrm{IU} / \mathrm{L})$ was not statistically different from the silymarin administered group. Supplementary data are given in Table S3.

\section{Total bilirubin}

As given in Fig. $5 d$, it was observed that paracetamol intoxication significantly raised $(p \leq 0.05)$ the level of total bilirubin $(1.055 \mathrm{mg} / \mathrm{dL})$ in comparison to the control group $(0.157 \mathrm{mg} / \mathrm{dL})$. However, pre-treatment of animals with 50,100 , and $200 \mathrm{mg} / \mathrm{kg}$ bw dose of $\mathrm{MHC}$ revealed a significant reduction in total bilirubin with values of $0.560,0.348$, and $0.313 \mathrm{mg} / \mathrm{dL}$ respectively. The degree of protection was observed to be increased in a dose-responsive manner. Silymarin treatment afforded protection against injurious effects of paracetamol by displaying the value of $0.213 \mathrm{mg} / \mathrm{dL}$. Further, $\mathrm{MHC}$ at the mid and highest dose (100 and $200 \mathrm{mg} / \mathrm{kg} \mathrm{bw})$ and the silymarin group displayed no significant variation $(p \leq 0.05)$ when compared with normal control. This also indicated that $\mathrm{MHC}$ revealed a similar protective effect to that of silymarin. Also, it was noted that MHC per se did not display any adverse outcome as there was no significant difference in the parameter studied in comparison to the normal group. Supplementary data are given in Table S3.

\section{Phase-I reaction enzymes}

\section{NADPH-cytochrome P450 reductase (CPR)}


A significant augmentation (41.62 IU/mg protein) in enzyme level of CPR was seen in the paracetamol treated group as compared to the untreated group $(16.89 \mathrm{IU} / \mathrm{mg}$ protein) at $p \leq 0.05$. While preadministration of $\mathrm{MHC}$ witnessed a reduction in the enzyme level with values $33.43,23.74$, and 11.46 IU/mg protein in a dose-dependent way i.e. at 50,100 , and $200 \mathrm{mg} / \mathrm{kg}$ bw respectively (Fig. $6 \mathrm{a}$ ). In the present findings, it was seen that the mid and highest dose of MHC (100 and $200 \mathrm{mg} / \mathrm{kg} \mathrm{bw}$ ) reflected the better effect in bringing down the elevated level to near basal value as no statistical significance at $p \leq$ 0.05. Similarly, silymarin rendered protection against the toxic effects of paracetamol and showed an enzymatic value of $21.93 \mathrm{IU} / \mathrm{mg}$ protein which was comparable to the normal group. In MHC per se group, the value was found to be $14.35 \mathrm{IU} / \mathrm{mg}$ protein and did not reach any statistical significance when compared with normal control indicating no sign of toxicity by the highest dose itself. Supplementary data are given in Table S4.

\section{NADH-cytochrome b5 reductase (b5R)}

In the present findings, the level of b5R was markedly increased $(27.11 \mathrm{IU} / \mathrm{mg}$ protein) in the paracetamoltreated group as compared to the untreated group (11.82 IU/mg protein). As observed from Fig. $6 \mathrm{~b}$, statistical analysis between the normal and paracetamol groups revealed a significant difference at $p \leq$ 0.05 . MHC pre-treatment attenuated the paracetamol-induced hepatic dysfunction by reducing the values to $21.73,11.50$, and $6.027 \mathrm{IU} / \mathrm{mg}$ protein in a dose-dependent manner at the doses of 50,100 , and 200 $\mathrm{mg} / \mathrm{kg}$ bw respectively. However, the mid and highest dose of MHC (100 and $200 \mathrm{mg} / \mathrm{kg} \mathrm{bw}$ ) and silymarin pre-administration exhibited a statistical similarity with the normal group. Meanwhile, MHC alone when administered to rats showed the value of $11.86 \mathrm{IU} / \mathrm{mg}$ protein and revealed no significant effect $(p \leq 0.05)$ with the parameter being comparable to normal control animals. Supplementary data are given in Table $S 4$.

\section{Phase-II reaction enzymes}

Glutathione-S-transferase (GST): Fig. $6 \mathrm{c}$ represents the specific activity of the GST enzyme in different experimental groups. It was found that after a single high dose of paracetamol ( $3 \mathrm{~g} / \mathrm{kg} \mathrm{bw})$, the activity of GST was markedly decreased $(1.840 \mathrm{IU} / \mathrm{mg}$ protein) in comparison to the control group $(7.390 \mathrm{IU} / \mathrm{mg}$ protein). A significant difference $(p \leq 0.05)$ in the level of GST of the normal and paracetamol group was noticed. Pre-treatment of animals with three different doses of $\mathrm{MHC}(50,100$, and $200 \mathrm{mg} / \mathrm{kg} \mathrm{bw})$ and silymarin ( $50 \mathrm{mg} / \mathrm{kg} \mathrm{bw}$ ) elevated the expression of enzymes to $3.705,4.767,5.958$, and $6.766 \mathrm{IU} / \mathrm{mg}$ protein respectively. Further, it was observed that $200 \mathrm{mg} / \mathrm{kg}$ bw dose of MHC and silymarin significantly increased the level of enzyme and restored the activity to the values that were statistically similar to the normal group at a $5 \%$ level of significance. While in MHC per se group, the enzymatic value was seen to be $4.513 \mathrm{IU} / \mathrm{mg}$ protein. Supplementary data are given in Table S4.

\section{DT-diaphorase (DTD)}

In the present design of the experiment, paracetamol administration to Group II animals resulted in the depletion of specific activity of DTD enzyme $(2.768 \mathrm{IU} / \mathrm{mg}$ protein) as compared to the control group 
(6.944 IU/mg protein). Group comparison between the two revealed a significant difference at a $5 \%$ level of significance. Pre-administration of animals with MHC offered protection against the depleted enzymatic activity. At all the tested doses of combination i.e. 50, 100, and $200 \mathrm{mg} / \mathrm{kg}$ bw, the enzymatic activity was recovered displaying values $3.599,5.326$, and $5.679 \mathrm{mg} / \mathrm{kg}$ bw respectively (Fig. 6d). However, the mid and highest dose (100 and $200 \mathrm{mg} / \mathrm{kg} \mathrm{bw}$ ) represented statistical similarity at $p \leq 0.05$ with the normal group. Similarly, there was no significant difference in the activity of the enzyme under study in silymarin pre-treated rats $(7.181 \mathrm{IU} / \mathrm{mg}$ protein) and normal rats. Also, the value was observed to be $4.434 \mathrm{IU} / \mathrm{mg}$ protein on the administration of animals with MHC $(200 \mathrm{mg} / \mathrm{kg} \mathrm{bw})$ alone which was not seen to be apparent with the normal control. Supplementary data are given in Table S4.

\section{Membrane-bound enzymes}

\section{$\mathrm{Na}^{+} / \mathrm{K}^{+}$-ATPase}

The activity of $\mathrm{Na}^{+} / \mathrm{K}^{+}$-ATPase in the liver of different treatment groups is presented in Fig. 7a. The level of this enzyme was significantly decreased $(p \leq 0.05)$ in paracetamol-challenged animals $(0.129 \mu \mathrm{M}$ phosphorous liberated $/ \mathrm{min} / \mathrm{mg}$ protein) when compared with normal rats $(0.377 \mu \mathrm{M}$ phosphorous liberated/min/mg protein). On the contrary, the level of $\mathrm{Na}^{+} / \mathrm{K}^{+}$-ATPase was seen to be increased in a dose-responsive manner when animals were pre-administered with MHC i.e. the values were $0.155,0.184$, and $0.211 \mu \mathrm{M}$ phosphorous liberated $/ \mathrm{min} / \mathrm{mg}$ protein at 50,100 , and $200 \mathrm{mg} / \mathrm{kg}$ bw dose respectively. However, as revealed by statistical analysis, the highest dose of $\mathrm{MHC}$ exhibited a value similar to the silymarin treated group $(0.288 \mu \mathrm{M}$ phosphorous liberated $/ \mathrm{min} / \mathrm{mg}$ protein $)$ with no statistical difference at a $5 \%$ level of significance. Also, the activity of this enzyme was seen to be $0.262 \mu \mathrm{M}$ phosphorous liberated/min/mg protein when animals were given MHC at $200 \mathrm{mg} / \mathrm{kg}$ bw dose per se, showing statistical similarity with the untreated control. Supplementary data are given in Table S5.

$\mathrm{Ca}^{2+}$-ATPase: Fig. $7 \mathrm{~b}$ shows the modulatory effect of MHC pre-treatment on paracetamol-induced altered $\mathrm{Ca}^{2+}$-ATPase activity in the liver tissue of different treatment groups. A significant decrease ( $p \leq$ $0.05)$ in the level $(0.114 \mu \mathrm{M}$ phosphorous liberated $/ \mathrm{min} / \mathrm{mg}$ protein) was observed in the paracetamol group in comparison to the basal value in control animals $(0.633 \mu \mathrm{M}$ phosphorous liberated $/ \mathrm{min} / \mathrm{mg}$ protein). While, the activity of the enzyme was found to be increased in MHC at a dose of 50, 100, and $200 \mathrm{mg} / \mathrm{kg}$ bw $(0.180,0.287$, and $0.499 \mu \mathrm{M}$ phosphorous liberated $/ \mathrm{min} / \mathrm{mg}$ protein respectively) in a dose-responsive way counteracting the adverse effects of paracetamol intoxication. Similarly, the level of $\mathrm{Ca}^{2+}$-ATPase in the silymarin pre-treated group was seen to be $0.526 \mu \mathrm{M}$ phosphorous liberated $/ \mathrm{min} / \mathrm{mg}$ protein. Based on the statistical comparison, it was revealed that pre-treatment with the highest dose of MHC (200 mg/kg bw) and silymarin were equally effective in normalizing the diminished enzyme level. In addition to this, it was also found that exposure of animals to $\mathrm{MHC}$ alone did not significantly alter the parameter under study when compared with normal animals in group I. Supplementary data are given in Table S5. 
Intoxication of animals with paracetamol resulted in a significant decrease $(p \leq 0.05)$ in $\mathrm{Mg}^{2+}$-ATPase activity $(0.544 \mu \mathrm{M}$ phosphorous liberated/min/mg protein) in comparison to control group $(1.563 \mu \mathrm{M}$ phosphorous liberated/min/mg protein) (Fig. 7c). However, pre-treatment of animals with MHC increased the level of this membrane-bound enzyme in a dose-responsive manner with values $0.886,1.048$, and $1.359 \mu \mathrm{M}$ phosphorous liberated/min/mg protein at 50,100 , and $200 \mathrm{mg} / \mathrm{kg}$ bw dose respectively and protected the animals against paracetamol provoked membrane damage. Likewise, a decline in the specific activity of the enzyme was counteracted by silymarin pre-treatment $(1.786 \mu \mathrm{M}$ phosphorous liberated/min/mg protein). It was seen that both the highest dose of MHC (200 mg/kg bw) and silymarin ( $50 \mathrm{mg} / \mathrm{kg} \mathrm{bw}$ ) demonstrated statistically similar values as that of the normal group. Also, MHC alone exhibited the value of $1.396 \mu \mathrm{M}$ phosphorous liberated $/ \mathrm{min} / \mathrm{mg}$ protein with no significant difference at $p \leq 0.05$ as compared to untreated control. Supplementary data are given in Table S5.

\section{Oxidant/antioxidant biomarkers}

\section{Oxidant biomarkers}

\section{Lactate dehydrogenase (LDH)}

The animals treated with a single toxic dose $(3 \mathrm{~g} / \mathrm{kg}$ bw) of paracetamol developed significant hepatic injury as observed from elevated level $(49.55 \mathrm{IU} / \mathrm{mg}$ protein) of LDH enzyme in comparison to the control group (10.10 IU/mg protein). Statistical comparison between both these groups displayed a significant difference at $p \leq 0.05$. Pre-feeding of animals with MHC afforded protection against paracetamolinduced elevation in a dose-responsive way, i.e. the values were found to be $38.22,26.68$, and 16.54 $\mathrm{IU} / \mathrm{mg}$ protein at 50,100 , and $200 \mathrm{mg} / \mathrm{kg}$ bw dose respectively (Fig. 8a). The LDH level was seen to be $7.901 \mathrm{IU} / \mathrm{mg}$ protein in the silymarin administered group. Meanwhile, the highest dose $(200 \mathrm{mg} / \mathrm{kg} \mathrm{bw})$ of $\mathrm{MHC}$ and silymarin represented no statistical significance $(p \leq 0.05)$ with the normal group. However, a comparison between these two treatments illustrated a significant difference. Supplementary data are given in Table S6.

\section{Lipid peroxidation (LPO)}

In the present investigation, the normal basal value of TBARS content was seen to be $48.54 \mu \mathrm{M}$ MDA equivalent/g tissue while paracetamol treatment raised the value to $157.9 \mu \mathrm{M}$ MDA equivalent/g tissue which was significantly highest ( $p \leq 0.05)$ among all treatment groups. However, MHC at 50, 100, and $200 \mathrm{mg} / \mathrm{kg}$ bw declined the formation of TBARS to $117.0,92.4$, and $63.16 \mu \mathrm{M}$ MDA equivalent $/ \mathrm{g}$ tissue respectively in a dose-responsive way (Fig. 8b). MHC per se and silymarin group animals displayed TBARS content of 52.63 and $56.73 \mu \mathrm{M}$ MDA equivalent/g tissue. Further, it was elucidated that the highest dose of $\mathrm{MHC}$ and silymarin displayed no statistical difference at $p \leq 0.05$ when compared with the normal group. Thus, the effect rendered by the highest dose was equivalent to that of standard silymarin. Also, the statistical similarity between $\mathrm{MHC}$ alone and the normal group represented no significant toxicity of combination by itself. Supplementary data are given in Table S6. 


\section{Lipid hydroperoxides}

The amount of lipid hydroperoxides in group I rats was observed to $0.913 \mathrm{mM} \mathrm{H}_{2} \mathrm{O}_{2}$ equivalent/g tissue. This value was considered a normal basal value. Paracetamol intoxicated animals showed the maximum amount of lipid hydroperoxides among all treatment groups ( $4.807 \mathrm{mM} \mathrm{H}_{2} \mathrm{O}_{2}$ equivalent/g tissue) and represented a significant difference at $p \leq 0.05$. Animals pre-treated with $\mathrm{MHC}$ at the dose of 50,100 , and $200 \mathrm{mg} / \mathrm{kg}$ bw afforded the protection in a dose-dependent manner and exhibited lipid hydroperoxide content of 3.766, 2.218, and $1.149 \mathrm{mM} \mathrm{H}_{2} \mathrm{O}_{2}$ equivalent/g tissue respectively (Fig. 8c). MHC at 200 $\mathrm{mg} / \mathrm{kg}$ bw dose per se displayed $1.920 \mathrm{mM} \mathrm{H}_{2} \mathrm{O}_{2}$ equivalent/g tissue and animals pre-treated with silymarin showed the lipid hydroperoxide content close to the basal value $\left(0.960 \mathrm{mM} \mathrm{H}_{2} \mathrm{O}_{2}\right.$ equivalent/g tissue). From the results, it was noticed that $100 \mathrm{mg} / \mathrm{kg}$ bw and $200 \mathrm{mg} / \mathrm{kg}$ dose of MHC showed no significant difference in lipid hydroperoxide content as compared to the untreated control group. Also, the statistical similarity between $\mathrm{MHC}$ per se and the normal group presented no appreciable toxicity of combination. Supplementary data are given in Table S6.

\section{Protein content}

The variations in the protein content displayed by animals in different experimental groups are given in Fig. 8d. Group I animals that served as normal control exhibited the highest amount of protein content ( $91.57 \mathrm{mg} / \mathrm{g}$ tissue) while Group II animals that were given a highly toxic dose ( $3 \mathrm{~g} / \mathrm{kg} \mathrm{bw}$ ) of paracetamol showed the minimum amount of protein content $(29.45 \mathrm{mg} / \mathrm{g}$ tissue $)$ among all treatment groups. This variation was observed to be statistically different at $p \leq 0.05$. The animals pre-treated with $\mathrm{MHC}$ at three doses $(50,100$, and $200 \mathrm{mg} / \mathrm{kg} \mathrm{bw}$ ) showed the dose-dependent increase in protein content i.e. $41.28,60.53$, and $76.40 \mathrm{mg} / \mathrm{g}$ tissue respectively. The protein content displayed by the highest dose of MHC and silymarin exhibited no significant difference $(p \leq 0.05)$ when compared with the normal group. In addition, $\mathrm{MHC}$ at $200 \mathrm{mg} / \mathrm{kg}$ bw dose per se exhibited $83.86 \mathrm{mg} / \mathrm{g}$ protein content and presented statistical similarity with normal rats at a $5 \%$ level of significance indicating no toxic effect. Supplementary data are given in Table S6.

\section{Antioxidant biomarkers}

\section{Reduced glutathione(GSH)}

In the present findings, it was seen from Fig. 9a that rats fed on a normal diet exhibited $410.5 \mu \mathrm{M} \mathrm{SH}$ content/g tissue while paracetamol challenged rats showed significant reduction $(p \leq 0.05)$ in the level i.e. $151.4 \mu \mathrm{M} \mathrm{SH}$ content/g tissue. Pre-treatment of rats with MHC at doses 50,100 , and $200 \mathrm{mg} / \mathrm{kg} \mathrm{bw}$ significantly restored the level of glutathione content in a dose-responsive manner exhibiting values 199.5, 261.1, and 307.7 $\mu \mathrm{M}$ SH content/g tissue respectively. Silymarin also reversed the adverse effect elicited by hepatotoxin and showed the value $366.1 \mu \mathrm{M} \mathrm{SH}$ content/g tissue. Animals that were given $\mathrm{MHC}$ alone exhibited $348.3 \mu \mathrm{M} \mathrm{SH}$ content/g tissue. In addition, MHC per se and silymarin group revealed 
no significant differences at $p \leq 0.05$. Overall, the experimental groups I to VI showed statistical difference at a $5 \%$ level of significance. Supplementary data are given in Table S7.

\section{Superoxide dismutase (SOD)}

The specific enzymatic activity of SOD was evaluated in different treatment groups and results are presented in Fig. 9b. It was observed that the toxicity promoted by paracetamol markedly reduced $(p \leq$ 0.05 ) the enzymatic activity ( $84.42 \mathrm{IU} / \mathrm{mg}$ protein) as compared to basal control value $179.0 \mathrm{IU} / \mathrm{mg}$ protein. The administration of MHC raised the level of SOD in a dose-dependent manner i.e. 100.2, 121.7, and $155.2 \mathrm{IU} / \mathrm{mg}$ protein at 50,100, and $200 \mathrm{mg} / \mathrm{kg}$ bw respectively. Meanwhile, the highest dose of MHC $(200 \mathrm{mg} / \mathrm{kg} \mathrm{bw})$ restored the paracetamol mediated altered enzymatic level with statistical similarity to that of the normal group. Similarly, the silymarin-treated group also raised the level of hepatic antioxidant enzyme effectively (203.8 IU/mg protein) and indicated no statistical variation when compared with normal control. MHC alone exhibited enzymatic activity with a value of $124.2 \mathrm{IU} / \mathrm{mg}$ protein.

Supplementary data are given in Table S7.

\section{Catalase (CAT)}

The activity of CAT was significantly depleted $(p \leq 0.05)$ in the liver of rats intoxicated with paracetamol. The enzymatic value was calculated to be $4.901 \mathrm{IU} / \mathrm{mg}$ protein as compared to the control value, i.e. $15.23 \mathrm{IU} / \mathrm{mg}$ protein as observed in the normal group. In contrast, pre-treatment of MHC was observed to be effective in boosting the CAT activity in a dose-dependent manner and reflected $6.145,10.01$, and $12.60 \mathrm{IU} / \mathrm{mg}$ protein at 50,100, and $200 \mathrm{mg} / \mathrm{kg}$ bw dose respectively (Fig. 9c). The treatment of the highest dose of MHC (200 mg/kg bw) prior to paracetamol intoxication represented no significant deviation at $p \leq 0.05$ as compared to the normal group. Similarly, silymarin pre-administration raised the enzymatic level to $13.71 \mathrm{IU} / \mathrm{mg}$ protein and manifested statistical similarity with Group I normal animals $(p \leq 0.05)$. In addition, the enzymatic value was observed to be $8.552 \mathrm{IU} / \mathrm{mg}$ protein in animals that were given $200 \mathrm{mg} / \mathrm{kg}$ bw dose of MHC alone. However, this value was not observed to be apparent with the basal value. Supplementary data are given in Table S7.

\section{Glutathione peroxidase (GPx)}

The level of hepatic GPx was measured in all treatment groups and results are shown in Fig. 9d. The activity of the enzyme was significantly diminished in the paracetamol exposed group $(3.172 \mathrm{IU} / \mathrm{mg}$ protein) in comparison to the normal control $(11.56 \mathrm{IU} / \mathrm{mg}$ protein) at a $5 \%$ level of significance. Pretreatment with 50,100 , and $200 \mathrm{mg} / \mathrm{kg}$ bw dose of MHC significantly augmented the antioxidant enzyme level (4.586, 7.358, and $10.52 \mathrm{lU} / \mathrm{mg}$ protein) in a dose-dependent way. It was observed from the results that the highest dose of $\mathrm{MHC}$ was effective in restoring the reduced enzyme level to near normal as it did not represent a significant difference at $p \leq 0.05$. In the same way, the value was seen to be $11.11 \mathrm{IU} / \mathrm{mg}$ protein in the silymarin administered group which also did not reach any statistical difference in comparison to the control. Simultaneously, it was also seen that MHC (200 mg/kg bw) and silymarin (50 $\mathrm{mg} / \mathrm{kg} \mathrm{bw}$ ) showed statistical similarity, raising the possibility that the highest dose of MHC is effective 
in restoring the altered enzyme activity as that of standard silymarin. Supplementary data are given in Table S7.

\section{Glutathione reductase (GR)}

The changes in specific activity of GR among different treatment groups are shown in Fig. 9e. Hepatic damage provoked by paracetamol resulted in a significant diminution (5.357 IU/mg protein) when compared with animals of the control group (17.23 IU/mg protein) at $p \leq 0.05$. While, the preadministration of $\mathrm{MHC}$ indicated a dose-dependent rise in the level of GR i.e. 7.222, 10.28, and 16.37 $\mathrm{IU} / \mathrm{mg}$ protein at 50, 100, and $200 \mathrm{mg} / \mathrm{kg}$ bw respectively. It was found that the highest dose caused a successive revival towards normalization as the statistical comparison did not reveal a significant difference $(p \leq 0.05)$ when compared with the normal group. Further, silymarin treatment and MHC per se at the dose of $200 \mathrm{mg} / \mathrm{kg}$ bw illustrated no significant difference and showed the values of 12.10 and $12.71 \mathrm{IU} / \mathrm{mg}$ protein respectively. Supplementary data are given in Table S7.

\section{Histopathological findings}

Gross necropsy of the liver of all the treatment groups was conducted to observe any abnormal or irregular changes in the appearance of liver lobes. It was seen that the liver of Group I control animals was dark maroon with a smooth surface. While the liver of paracetamol intoxicated rats showed changes in colour and appearance. The liver lobes were more or less brown with irregular white spots as depicted in Fig. 10. These gross abnormalities were remarkably reduced when animals were pre-treated with $\mathrm{MHC}$ and silymarin.

Further, the histopathological examination of liver tissues was done using Ishak modified HAI grading to determine the necroinflammatory scores in different treatment groups. The various features of hepatic injury are displayed in Table 2 and Fig. 11. The sections of liver tissues of animals treated with paracetamol (3 g/kg bw) showed marked hepatic damage with extensive panacinar/multiacinar necrosis, coagulative type necrosis of hepatocytes, loss of cellular boundaries, apoptosis, portal triad inflammation with the highest score (10/18) as seen from Table 2. On the other hand, liver sections of the control group depicted healthy normal hepatocytes with well-defined sinusoidal spaces and a central vein scoring 0/18. Similarly, in MHC (200 mg/kg bw) per se group, the hepatocytes did not show any significant sign of necrosis or degeneration and well preserved hepatic cells with cytoplasm and nucleus were observed. Paracetamol provoked massive necrosis and inflammation was significantly improved in $\mathrm{MHC}$ pretreated rats in a dose-responsive manner. Group pre-treated with the lowest dose (50 mg/kg bw) had mild to moderate piecemeal necrosis, focal confluent necrosis in some areas with mild focal and portal inflammation (score 4/18). The medium dose (100 mg/kg bw) demonstrated mild focal inflammation with no sign of confluent necrotic region (2/18) indicating partial protection of hepatocytes. The highest dose (200 mg/kg bw) afforded the marked protection and represented the normal architecture of hepatocytes with no necrotic zones. However, mild portal inflammation was seen and the grading score was calculated to be $1 / 18$. Also, in the silymarin treated group, no major abnormality or irregularity in the 
structure of hepatic cells was observed. Overall, the Kruskal-Wallis $\mathrm{H}$ test revealed a statistically significant difference in necroinflammatory scores between different treatment groups (I-VII). The necroinflammatory scores for "periportal or periseptal interface hepatitis (piecemeal necrosis)" were significantly different between treatment groups (I-VII) with $H=28.24, p=0.000085$ and $d f=6$. Similarly, the necroinflammatory scores for "confluent necrosis" ( $H=35.82, p=0.000003$ and $d f=6)$, "focal (spotty) lytic necrosis, apoptosis, and focal inflammation" ( $H=31.89, p=0.000017$ and $d f=6)$ and "portal inflammation" ( $H=30.06, p=0.000038$ and $d f=6)$ were significantly different between treatment groups (I-VII). The corresponding average rank scores of groups (I-VII) with pairwise comparisons for twenty-one pairs of groups by Dunn-Bonferroni post hoc test are shown in Fig. 12a, 12b, 12c and 12d. There was strong evidence of difference at $p \leq 0.05$ (adjusted by the Bonferroni correction) between treatment group II with group I, group III, group VI, and group VII. Moreover, there was statistically no significant difference among groups I, III, $\mathrm{VI}$, and $\mathrm{VII}$ revealing the effectiveness of $\mathrm{MHC}$ by overturning the paracetamol-induced hepatotoxicity in rats. 
Table 2

Summary of the hepatic necroinflammatory score in Ishak modified HAI scoring of all treatment groups

\begin{tabular}{|c|c|c|c|c|c|c|}
\hline $\begin{array}{l}\text { Group } \\
(n= \\
6)\end{array}$ & $\begin{array}{l}\text { Treatment } \\
\text { type }\end{array}$ & $\begin{array}{l}\text { Perportal or } \\
\text { periseptal } \\
\text { interface } \\
\text { hepatitis } \\
\text { (piecemeal } \\
\text { necrosis) }\end{array}$ & $\begin{array}{l}\text { Confluent } \\
\text { necrosis }\end{array}$ & $\begin{array}{l}\text { Focal (spotty) } \\
\text { lytic necrosis, } \\
\text { apoptosis and } \\
\text { focal } \\
\text { inflammation }\end{array}$ & $\begin{array}{l}\text { Portal } \\
\text { inflammation }\end{array}$ & $\begin{array}{l}\text { Grading } \\
\text { score }\end{array}$ \\
\hline I & $\begin{array}{l}\text { Normal } \\
\text { control }\end{array}$ & 0 & 0 & 0 & 0 & $0 / 18$ \\
\hline II & $\begin{array}{l}\text { Paracetamol } \\
\text { (3 g/kg bw) }\end{array}$ & 1 & 6 & 2 & 1 & 10/18 \\
\hline III & $\begin{array}{l}\text { MHC (200 } \\
\mathrm{mg} / \mathrm{kg} \text { bw) } \\
\mathrm{per} \mathrm{se}\end{array}$ & 0 & 0 & 0 & 0 & $0 / 18$ \\
\hline IV & $\begin{array}{l}\text { MHC (50 } \\
\mathrm{mg} / \mathrm{kg} \mathrm{bw}) \\
+ \\
\text { Paracetamol }\end{array}$ & 1 & 1 & 1 & 1 & $4 / 18$ \\
\hline V & $\begin{array}{l}\text { MHC (100 } \\
\mathrm{mg} / \mathrm{kg} \mathrm{bw}) \\
+ \\
\text { Paracetamol }\end{array}$ & 1 & 0 & 1 & 0 & $2 / 18$ \\
\hline VI & $\begin{array}{l}\text { MHC (200 } \\
\mathrm{mg} / \mathrm{kg} \mathrm{bw}) \\
+ \\
\text { Paracetamol }\end{array}$ & 0 & 0 & 0 & 1 & $1 / 18$ \\
\hline VII & $\begin{array}{l}\text { Silymarin } \\
(50 \mathrm{mg} / \mathrm{kg} \\
\text { bw })+ \\
\text { Paracetamol }\end{array}$ & 0 & 0 & 0 & 0 & $0 / 18$ \\
\hline
\end{tabular}

\section{Discussion}

Antioxidant phytoconstituents have the ability to overturn the toxic alterations in the liver by reducing oxidative stress and inflammatory responses (Jeyadevi et al. 2019). The hepatoprotective effect of MHC could be correlated to the presence of high amounts of kaempferol, ellagic acid, and gallic acid. Structurally, high planarity due to the existence of three $\mathrm{OH}$ groups on the chroman ring in kaempferol contributes to the efficacious radical scavenging capacity (Kim and Lee 2004). The antioxidant action of ellagic acid is supported by high 5-0 radical stability via maintaining overall spin density delocalization due to dual orthodiphenolic functionalities of this polyphenol (Chen et al. 2015). The benzene ring of gallic acid has three vicinal hydroxyl groups which enhance the antioxidant ability of this compound (Kim and Lee 2004). Overall, the effective hepatoprotective ability of MHC can correlate to the vicinal substitution of $\mathrm{OH}$ functional groups on catechol moiety, 4-oxo functionality with 2,3- double bonds 
conjugation, and presence of 3- and 5-OH functional groups on chroman ring (Kim and Lee 2004). The possible synergistic effect of polyphenols in MHC may be attributed to the high synchrony within polyphenolic structures and efficacious electron/hydrogen donating capability. Bioavailability is a crucial endpoint for documentation of in vivo effective action of nutritional commodities (de Pascual-Teresa et al. 2010). As reported in our previous study, the protective ability of MHC in liver cells might be attributed to the higher bioavailability of antioxidants at cellular levels due to the water-soluble characteristics of MHC (Kaur et al. 2019).

Paracetamol (acetaminophen; $\mathrm{N}$-acetyl-p-aminophenol) is a commonly utilized antipyretic and analgesic drug worldwide. It is considered safe when taken at a therapeutic dose. However, its overdose has been documented to cause acute liver poisoning and is one of the most frequently reported products promoting DILI (Yoon et al. 2016; Tittarelli et al. 2017). Phenolic phytochemicals can impact APAP metabolism, effectiveness, and toxicity. These compounds can affect its bioavailability via a variety of mechanisms, including competition with cytochrome P450 (CYP) enzymes, esterases, uridine diphosphate glucuronosyltransferases, and transporters including P-glycoprotein, organic anion transporting polypeptides, breast cancer resistance protein, multidrug resistance-associated proteins, and monocarboxylate transporters (Abdel-Daim et al. 2018).

In the present study, the statistically insignificant differences in average body weight did not reveal any signs of paracetamol-induced hepatotoxicity in rats as compared to the normal control group. Similar results were observed in a previous study on paracetamol-induced toxicity in rats (Mahmood et al. 2014). The study revealed that the ratio of liver weight to body weight is a better approach for observing the toxic effects. The aggregation of extracellular matrix protein and collagen in liver tissue can be linked to the toxic enlargement of the liver caused by paracetamol. However, our study did not reveal significant enlargement of the liver as compared to the normal control group. The haematopoietic system is considered a unique target for haematotoxins due to its high susceptibility to the intoxication of xenobiotics or their secondary toxic effects. This may affect the supply of iron and nutrients, production of erythropoietin, clearance of urea, and other essential functions which in turn alter the normal range of different blood cells like erythrocytes, leucocytes, and platelets (Adeneye et al. 2008). Results of the present study showed that haematological changes induced by paracetamol had the haematotoxic effect and $\mathrm{MHC}$ showed the potential protective activity against this effect. The parameters like haematocrit, haemoglobin, total RBCs, total WBCs, and platelet count were significantly decreased relative to normal control due to interference in the rate of erythropoiesis associated with overdose of paracetamol. However, oral pre-treatment with MHC at $200 \mathrm{mg} / \mathrm{kg}$ bw dose reduced the deleterious effect of haematotoxic injury with subsequent augmentation of these haematological indices indicating synthesis of blood cells. This might be attributed to the possibility that interaction among constituents (phenolic acids, flavonoids, and other bioactive constituents) in MHC could have stimulated the formation or secretion of erythropoietin, haematopoietic growth factors, and stem cells (Uboh et al. 2010). Previous studies have also demonstrated that under the conditions of hypoxia, herbal extracts activate the hypoxia response element signalling pathway to promote the mRNA and protein expression of erythropoietin (Lam et al. 2016). This might be the probable response of MHC in the present case to regulate the 
haematological profile from the adverse scenarios. In addition to this, MHC could have sheltered the blood cells from the assault of free radicals which can be related to its antioxidant efficacy as seen in CAP-e assay (Kaur et al. 2019). The protective effect of MHC in the present study is supported by results of the previous findings which reported that an aqueous ethanolic polyherbal mixture consisting of leaves of Gongronema latifolia, Vernonia amygdalina, and Ocimum gratissimum raised levels of most of the haematological parameters and annulled the haematopoietic injury promoted by paracetamol (Iroanya et al. 2014).

The hepato-specific markers i.e. SGOT, SGPT, ALP, and total bilirubin are deemed sensitive indicators of hepatocellular dysfunction (Kullak-Ublick et al. 2017). Hepatocytes participate in various metabolic functions and their destruction during hepatic injury substantiates efflux of their cytosolic content along with serum transaminases into extracellular spaces from where these enzymes enter into the circulatory stream (Ozer et al. 2008). ALP enzyme hydrolyzes monophosphatases at an alkaline pH and is associated with the cell membranes of hepatocytes. Generally, its elevation in serum represents biochemical abnormality indicating disruption of the plasma membrane (Ozer et al. 2008). The high concentration of bilirubin (haemoglobin degradation product) in serum is a marker of hepatobiliary injury which signifies its excessive excretion during damage to the hepatic parenchyma (Ozer et al. 2008; Nithianantham et al. 2011). In this study, paracetamol intoxication to rats significantly augmented liver function indices reflecting membrane damage and leakage of enzymes into the bloodstream. However, the amplified levels were ameliorated in a dose-dependent manner by pre-treatment with MHC. The normalisation of these serum markers with the administration of the highest dose was seen to be comparable with standard silymarin indicating the metabolic regulatory potential of MHC. The active phyto-ingredients in the combination might have facilitated the stabilization of plasma membrane affording protection to hepatic cells against paracetamol and ultimately preserved the structural and functional integrity of hepatocytes. Earlier studies have also reported that pre-treatment of animals with the herbal formulation comprising a spray-dried extract of Andrographis paniculata, Phyllanthus niruri, and Phyllanthus emblica for 5 days at 100 and $200 \mathrm{mg} / \mathrm{kg}$ bw dose significantly reduced the level of serum biomarkers provoked by paracetamol overdose (Tatiya et al. 2012). Another hepatoprotective study also presented similar results with pre-treatment of Livshis formulation regularizing transport function of liver cells (Bera et al. 2011; Bera et al. 2017).

In the phase-I system, the metabolism of paracetamol primarily involves its oxidation in the liver via CYP enzymes to make it more water-soluble and facilitates its easy removal from the body (Williams 2013). In this system, CYP-catalyzed metabolism of paracetamol forms intermediate hepatotoxic products like $\mathrm{N}$ acetyl-p-benzoquinone imine (NAPQI) and 3-hydroxy-acetaminophen (3-OH-APAP) (Gu et al. 2005, Abdeen et al. 2018). P450 enzymes (especially CYP1A2 and CYP2E1) play an important role in the metabolic activation of paracetamol to its toxic biotransformation. CPR is an obligate redox companion for all P450 enzymes and thus its elevated expression may signify the toxic biotransformation of paracetamol in the liver (Gu et al. 2005). In the present study, the significant augmentation of CPR indicated the hepatic biotransformation of paracetamol to its toxic byproducts in the paracetamol-treated group as compared to its expression in the untreated group. While it was seen that the highest dose of MHC brought down the 
elevated level of enzymes to the near basal value. The activity of MHC was observed to be dosedependent rendering protection against the toxic effects of paracetamol.

In catalytic biotransformation of paracetamol, the P450 cycle requires the sequential translocation of two electrons via CPR and b5R (Finn et al. 2008). Thus, more abundance of cytochrome b5 reductase along with CPR reveals the toxic biotransformation of paracetamol. In the present investigation, the level of b5R was markedly increased in the paracetamol-treated group. This analysis highlights the toxic biotransformation of paracetamol in rat liver as compared to the untreated group. It was observed that pre-treatment of $\mathrm{MHC}$ inhibited the excess augmentation of b5R at the highest dose facilitating diminution of toxic biotransformation of paracetamol. MHC pre-treatment attenuated the paracetamolinduced hepatic dysfunction by reducing the level of b5R in a dose-dependent way.

GST is an important enzyme for the detoxification of many xenobiotics from the liver. The enzyme catalyzes the conjugation of N-acetyl-p-benzoquinone imine (NAPQI) with a reduced form of intracellular glutathione, ultimately assisting in the excretion of NAPQI from the liver as conjugates of cysteine and mercapturic acid (McCrae et al. 2018). Thus, excess NAPQI causes antioxidant glutathione depletion which leads to oxidative stress. In the present study, the paracetamol-treated group revealed a reduction in the level of GST as compared to the control group. The highest dose of MHC $(200 \mathrm{mg} / \mathrm{kg} \mathrm{bw})$ augmented the level of this enzyme to near the level of the control group. The augmentation in enzymatic level was found to be in a dose-dependent manner.

DTD is an important enzyme that can scavenge superoxide anions formed as a consequence of oxidative stress and help in the reestablishment of endogenous reduced forms of defensive antioxidants (Aleksunes et al. 2006). DTD facilitates the metabolization of toxic byproduct (NAPQI) of paracetamol into harmless hydroquinone (Lancaster et al. 2015). The excess of paracetamol can reduce the level of enzyme in the liver, thereby causing abatement of enzymatic expression (Liu et al. 2016). The decreased expression may lead to aggravated toxicity in the liver. In the current study, it has been revealed that the specific activity of the DTD enzyme was significantly reduced in the paracetamol intoxicated group as compared to the control group. However, MHC treatment recovered the enzymatic level in a dosedependent manner with greater activity at the highest dose of $200 \mathrm{mg} / \mathrm{kg}$ bw comparable to the normal group.

ATPases are a class of energy-linked master enzymes in all organisms accountable for membrane permeability, transport of ions, and regulation of osmotic pressure (Al-Numair et al. 2015). The membrane-bound enzymes such as $\mathrm{Na}^{+} / \mathrm{K}^{+}, \mathrm{Ca}^{2+}$, and $\mathrm{Mg}^{2+}$-ATPases transport ions across the cell membrane at the expense of adenosine triphosphate. $\mathrm{Na}^{+} / \mathrm{K}^{+}$and $\mathrm{Ca}^{2+}-\mathrm{ATP}$ ase are actively associated with the transport of sodium, potassium, and calcium ions across the plasma membrane while $\mathrm{Mg}^{2+}$ ATPase directs intracellular magnesium ion concentration and regulates protein synthesis and cellular growth (Ji et al. 2009). In the present investigation, decreased activities of ATPases in the paracetamol administered group was observed. The inactivation of these enzymes in hepatotoxin administered group might be possibly due to their vulnerability to LPO induced as a result of over generation of free radicals 
(Bhagavathy and Sumathi 2012, Madkour and Abdel-daim 2013). Consistent with the previous studies (Bafna and Balaraman 2013; Padma et al. 2016), the present research revealed that following MHC pretreatment the activities of membrane-bound enzymes were raised. The polyphenolic compounds in the combination might have protected the membrane phospholipids from deleterious effects of peroxyl radicals by modulating the alteration in surface potential and membrane fluidity which in turn would have regularized enzymatic activities and cellular functions.

Another important enzyme linked with cellular integrity is LDH. During the absence of sufficient oxygen, it regulates the constant generation of ATP to sustain the glycolytic cycle. It regenerates $\mathrm{NAD}^{+}$by catalyzing the conversion of pyruvate to lactate in a reversible reaction (Augoff et al. 2015). However, the extensive-expression of this enzyme is related to its release into the blood or other body fluids during tissue breakdown. The intoxication of paracetamol elevated the level of LDH due to the damage exerted by free radicals or electrophiles generated as a consequence of induction of phase-I and reduction of phase-II enzymes. On the other hand, the activity of the enzyme was found to be lowered by the administration of herbal combination in a dose-responsive manner highlighting the potential of MHC in attenuating the toxic impact of paracetamol. The findings of Mayuren et al. (2010) also reported that Livactine containing extracts of nine medicinal plants at a dose of $2 \mathrm{~mL} / \mathrm{kg}$ significantly reduced the elevation of LDH along with other marker enzymes in serum. The authors correlated the resultant protective efficacy of formulation against paracetamol to the free radical scavenging property of phytoconstituents like flavonoids, alkaloids, and sterols.

Free radicals hit the lipid bilayer of cell membranes, stimulate the formation of lipid hydroperoxides and malondialdehydes, inactivate cellular proteins, membrane-bound enzymes and disrupt ionic homeostasis (Birben et al. 2012). The current study showed high lipid hydroperoxide and malondialdehyde content in the paracetamol group while pre-treatment with $\mathrm{MHC}$ demonstrated its reduction in a dose-dependent fashion. It was also noticed in in vitro experimental results that the MHC demonstrated the potential of scavenging peroxyl radicals in the LPO assay (Kaur et al. 2019). Hence extrapolating these results in liver homogenates, it might be feasible that the prophylactic effect of the combination is due to scavenging of free radicals and reactive oxygen species. Comparable with the findings in earlier studies reported by Olaleye et al. (2010), Parmar et al. (2010), Sabir et al. (2012) for various plant extracts, our results also indicated that bioactive constituents present in $\mathrm{MHC}$ might have been accountable for its capability to lessen the paracetamol exaggerated LPO.

The protein content in paracetamol intoxicated rats was observed to be the lowest among the studied animal groups. The reactive oxygen species in rats generated as a result of paracetamol metabolism might have targeted amino acids and promoted oxidative scission of DNA with altered activities of repair enzymes (Bkhairia et al. 2018). However, pre-treatment with MHC repressed proteolytic degradation possibly by regulating nucleic acid metabolism, preventing oxidative damage mediated structural modifications of proteins and hence promoting DNA and RNA formation. The results obtained as a consequence of administration of MHC are similar to findings where leaf extracts of Citrus hystrix and $C$. maxima increased the protein content (Abirami et al. 2015). 
GSH is an essential non-enzymatic antioxidant abundantly present in nuclei, mitochondria, and cytosol. It acts as a co-factor for GST and GR. The reduction in its content is coupled to excessive generation and amassing of reactive oxygen species that ultimately perturb the structural and functional homogeneity of cell organelles and their membranes (Sharma et al. 2010). In the present study, paracetamol exercised its detrimental effects by dropping the content of GSH. Moreover, the specific activity of GR was also diminished in paracetamol intoxicated animals, which was observed to be analogous with depletion of GSH content in liver homogenate of animals. MHC significantly elevated the level of GSH in a dosedependent manner rendering it to endorse the conjugating abilities in order to detoxify toxic entities. The results of the present study seem to be conceivable with that obtained by Singh et al. (2016) who reported that combined administration of Solanum xanthocarpum and Juniperus communis fruit extracts significantly potentiated their protective effect in comparison to their effect per se. The biological system is equipped with a set of antioxidative defence grids offering a network of protective strategies to avert and deactivate the free radical aggravated oxidation of DNA, proteins, lipids, and other essential biomolecules (Ighodaro and Akinloye 2017). In the present research, the response of animals that were given $\mathrm{MHC}$ was studied against paracetamol-induced oxidative damage by monitoring antioxidant enzymes like SOD, CAT, GPx, and GR. SOD catalyses the disproportionation of highly reactive superoxide anion radicals to hydrogen peroxide while CAT and GPx function to neutralize hydrogen peroxide to oxygen and water employing different substrates (Lobo et al. 2010; Kaur and Arora 2013). GPx also catalyses the reduction of peroxide radicals to oxygen and corresponding alcohols protecting organisms against oxidative damage. GR maintains a pool of GSH during cellular metabolism via catalyzing NADPH-dependent reduction of glutathione disulfide i.e. oxidised glutathione is recycled back to its reduced form (Couto et al. 2016). In the present study, decreased level of these enzymes in the paracetamol group might be related to their consumption in detoxification of excessive reactive oxygen species produced as a result of its toxicity. Another possibility of decreased specific activity of enzymes might be their suppression by the insult of reactive oxygen species. The pre-treatment with MHC at 50, 100 , and $200 \mathrm{mg} / \mathrm{kg}$ bw dose augmented the level of enzymes dose-dependently indicating the activation of enzymatic machinery to render protection to animals either by scavenging or inhibiting the formation of reactive oxygen species. An elevation in the specific activities of antioxidant enzymes has also been observed in a previous study following pre-treatment of animals with the herbal formulation comprising seven plants (Eclipta prostrata, Wedelia calendulaceae, Indigofera tinctoria, Sphaeranthus indicus, Centella asiatica, Acalypha indica, and Coldenia procumbens) against paracetamol-induced liver injury (Sen et al. 2015).

The protective action of MHC was further established by histopathological evaluation of the liver. The observations of paracetamol injured liver revealed confluent necrosis of hepatocytes but MHC pre-treated rats displayed normal architecture of hepatic cells. These findings were seen to be concurrent with liver function indices, antioxidant enzymes, and other oxidative stress parameters which showed values near to basal control against the toxic insult with paracetamol overdose. MHC was observed to be highly effective at $200 \mathrm{mg} / \mathrm{kg}$ bw dose revealing its possible protective action against paracetamol-induced hepatic dysfunction in rats. The effect of MHC was observed to be promising as it protected the hepatic 
tissues from histopathological alterations invoked due to paracetamol intoxication probably by scavenging the surplus free radicals, triggering antioxidant defense system, and stabilizing cellular membranes through inhibition of LPO. The results were comparable to earlier studies presented by Devaraj et al. (2011) and Tatiya et al. (2012) who also reported that polyherbal formulations present high potential in abrogating the pathological damage against paracetamol-induced hepatotoxicity and sustaining normal liver morphology. Finally, Fig. 13 depicts the possible protective action of MHC with mechanistic pathways against paracetamol-induced acute hepatotoxicity in female Wistar rats. The study revealed that MHC pre-administration overturned the APAP-mediated toxic alterations.

Herbs are natural resources of conventional, traditional, and complementary medicines, offering imperative therapeutic properties against many ailments. The present study gives the reflection that MHC treatment overturned the biochemical toxic alterations in rat liver against paracetamol-induced hepatic damage. Our previous study revealed that the hydrogen or electron-donating capability of bioactive phytoconstituents in $\mathrm{MHC}$ rendered the potential antioxidative action against in vitro oxidative stress. Further, the antiproliferative potential of MHC against HepG2 cells reflected the probable apoptotic mode of hepatoma cell death (Kaur et al. 2019). The biofunctional significance of herbal drugs emerges from the cumulative effect of synergistic interactions between several phytoconstituents and their specific affinity for many biological receptors in phytotherapeutic research (Carmona and Pereira 2013). The physiology of pathogenesis and disease progression encompasses multiple factors necessitating the transition of therapeutic approaches from conventional "single target-one drug" to "multiple targetmultidrug" model (Efferth and Koch 2011; Long et al. 2015). The multi-component herbal therapy endows the holistic action originating from multifaceted positive/negative interactions between components (Rather et al. 2013). The mechanistic basis of these interactions consisting of better bioavailability, modulation in cellular transport functions, pro-drug activation, and synergistic effect at different targets of the same cell signalling cascade is referred to as multi-target effect (Efferth and Koch 2011). Decisively, the present study apprehends the synergistic intervention of inherent phytoconstituents (kaempferol, ellagic acid, and gallic acid) in MHC which might have a multi-target prophylactic effect with better bioavailability due to effectual solubility in the aqueous medium. The study necessitates the investigation of the mechanistic basis of cumulative interaction among various phytoconstituents in $\mathrm{MHC}$ for its viable therapeutic action in complementary and alternative healthcare practices.

\section{Conclusion}

A multi-herbal combination of $P$. granatum, $P$. roxburghii, S. chirata, T. cordifolia, and T. corniculata with a proportion of $33,27,25,10$, and $5 \%$ respectively was evaluated against the acute drug-induced liver injury by paracetamol in female Wistar rats. It was discovered that MHC intercepted the paracetamol mediated toxic alterations in liver function indices and xenobiotic-metabolizing enzymes affording protection against hepatic dysfunction. The effect of MHC was observed to be promising as it protected the hepatic tissues from paracetamol-mediated alterations by scavenging the surplus free radicals, triggering antioxidant defence system, and stabilizing cellular membranes through inhibition of LPO which might be correlated to the synergistic effect of inherent phytoconstituents like kaempferol, ellagic acid, and 
gallic acid. These major findings advocate the enormous scope of $\mathrm{MHC}$ as a multiple target-multidrug model, after affirmative pharmacological investigations in the future. Thus, herbal formulations with a natural combination of active phytoconstituents may provide a viable alternative to modern medicines.

\section{Declarations}

\section{Ethics approval and consent to participate}

The in vivo experimentations were carried out in accordance with the norms and guidelines of Committee for the Purpose of Control and Supervision of Experiments on Animals (CPCSEA), Ministry of Environment and Forest, Government of India. The necessary humane care was provided and all efforts were undertaken to reduce the animal sufferings. The study was reviewed and duly approved by Institutional Animal Ethics Committee, Guru Nanak Dev University, Amritsar (approved protocol no. 226/CPCSEA/2014/19).

\section{Consent for publication}

Not applicable.

\section{Availability of data and materials}

All data generated or analysed during this study are included in this published article [and its supplementary information files].

\section{Competing interests}

The authors declare that they have no competing interests.

\section{Funding}

The present study was supported by the University Grants Commission (UGC)- New Delhi under the Maulana Azad National Fellowship scheme to the first author (vide grant no. 201213-MANF-2012-13-SIKPUN-16650). The authors duly acknowledge the financial assistance granted by the University Grants Commission (UGC)- New Delhi for instrumentation facility under UGC CPEPA and UPE program.

\section{Authors' contributions}

PK and RS performed the experiments, wrote the manuscript and contributed substantially to the design and execution of the study. RGM interpreted the data and contributed significantly to the writing of the manuscript. BS and SA provided the laboratory facility and helped in the designing of experimental procedures and data interpretations. All authors read and approved the final manuscript.

\section{Acknowledgement}


The authors are thankful to Mr. Viney and Mr. Sanjeev Kumar Kataria, HHRC Pvt. Ltd., Amritsar (Punjab) for helping in procurement and authentication of plant materials. The authors are grateful to Dr. Harpreet Singh Bhatia, CEO, Herbal Organic Agro Pharma (HOAP) Industries, Ludhiana (Punjab) for helping and providing the necessary facilities for the preparation of multi-herbal combination and Dr. Arpana Jain, Om Diagnostic, Kashmir Avenue, Amritsar (Punjab) for her help and support in histopathological analysis.

\section{References}

1. Abdeen A, Abdelkader A, Abdo M, Wareth G, Aboubakr M, Aleya L, Abdel-Daim M (2019) Protective effect of cinnamon against acetaminophen-mediated cellular damage and apoptosis in renal tissue. Environ Sci Pollut Res 26:240-249. https://doi.org/10.1007/s11356-018-3553-2

2. Abdel-Daim M, Abushouk Al, Reggi R, Yarla NS, Palmery M, Peluso I (2018) Association of antioxidant nutraceuticals and acetaminophen (paracetamol): Friend or foe? J Food Drug Anal 26(2S):S78-S87. https://doi.org/10.1016/j.jfda.2017.11.004

3. Abirami A, Nagarani G, Siddhuraju P (2015) Hepatoprotective effect of leaf extracts from Citrus hystrix and $C$. maxima against paracetamol induced liver injury in rats. Food Sci Hum Well 4:35-41

4. Adeneye AA, Olagunju JA, Beneho AS, Elias SO, Adisa AO, Idowu BO, Oyedeji MO, Isioye EO, Braimoh OB, Oladejo OO, Alana EO (2008) Nephroprotective effects of the aqueous root extract of Harungana madagascariensis (L.) in acute and repeated dose of acetaminophen renal injured rats. Int J Appl Res Nat Prod 1:6-14

5. Aebi H (1984) Catalase in vitro. In: Colowick SP, Kaplan NO (eds) Methods in enzymology, vol 105. Academic Press, New York, pp 121-126

6. Aleksunes LM, Goedken M, Manautou JE (2006) Up-regulation of NAD(P)H quinone oxidoreductase 1 during human liver injury. World J Gastroenterol 12:1937-1940

7. Al-Numair KS, Veeramani C, Alsaif MA, Chandramohan G (2015) Influence of kaempferol, a flavonoid compound, on membrane-bound ATPases in streptozotocin-induced diabetic rats. Pharm Biol 53:1372-1378

8. Anderson ME (1985) Determination of glutathione and glutathione disulfide in biological samples. In: Meister A (ed) Methods in enzymology, vol 113. Academic Press, New York, pp 548-551

9. Augoff K, Hryniewicz-Jankowska A, Tabola R (2015) Lactate dehydrogenase 5: an old friend and a new hope in the war on cancer. Cancer Lett 358:1-7

10. Bafna PA, Balaraman R (2013) Protective effect of DHC-1, a polyherbal formulation, against $\mathrm{CCl}_{4}$ induced liver damage. Hygeia J D Med 5:10-18

11. Bera TK, Chatterjee K, De D, Ali KM, Jana K, Maiti S, Ghosh D (2011) Hepatoprotective activity of Livshis, a polyherbal formulation in $\mathrm{CCl}_{4}$-induced hepatotoxic male Wistar rats: a toxicity screening approach. Genomic Med Biomarkers Health Sci 3:103-110

12. Bera TK, Chatterjee K, Jana K, Ali KM, De D, Maiti S, Ghosh D (2017) Antihepatotoxic effect of "Livshis," a polyherbal formulation against carbon tetrachloride-induced hepatotoxicity in male 
albino rat. J Nat Pharm 3:17-24

13. Bhagavathy S, Sumathi $P$ (2012) Stabilization of membrane bound ATPases and lipid peroxidation by carotenoids from Chlorococcum humicola in benzo(a)pyrene induced toxicity. Asian Pac J Trop Biomed 2:380-384

14. Birben E, Sahiner UM, Sackesen C, Erzurum S, Kalayci O (2012) Oxidative stress and antioxidant defense. World Allergy Organ J 5:9-19

15. Bkhairia I, Dhibi S, Nasri R, Elfeki A, Hfaiyedh N, Amara IB, Nasri M (2018) Bioactive properties: enhancement of hepatoprotective, antioxidant and DNA damage protective effects of golden grey mullet protein hydrolysates against paracetamol toxicity. RSC Adv 8:23230-23240

16. Bonting SL (1970) Sodium-potassium activated adenosine triphosphatase and cation transport. In: Bitter EE (ed) Membrane ion transport. Inter Science, Chichester, pp 257-263

17. Carlberg I, Mannervik B (1985) Glutathione reductase. In: Meister A (ed) Methods in enzymology, vol 113. Academic Press, New York, pp 484-490

18. Carmona F, Pereira AMS (2013) Herbal medicines: old and new concepts, truths and misunderstandings. Rev Bras Farmacogn 23:379-385

19. Chen Y, Xiao H, Zheng J, Liang G (2015) Structure-thermodynamics-antioxidant activity relationships of selected natural phenolic acids and derivatives: an experimental and theoretical evaluation. PLoS One 10:e0121276

20. Couto N, Wood J, Barber J (2016) The role of glutathione reductase and related enzymes on cellular redox homoeostasis network. Free Radical Biol Med 95:27-42

21. de Pascual-Teresa S, Moreno DA, García-Viguera C (2010) Flavanols and anthocyanins in cardiovascular health: a review of current evidence. Int J Mol Sci 11:1679-1703

22. Devaraj VC, Krishna BG, Viswanatha GL, Kamath JV, Kumar S (2011) Hepatoprotective activity of Hepax- a polyherbal formulation. Asian Pac J Trop Biomed 1:142-146

23. Devasagayam TP, Boloor KK, Ramasarma T (2003) Methods for estimating lipid peroxidation: an analysis of merits and demerits. Indian J Biochem Biophys 40:300-308

24. Efferth T, Koch E (2011) Complex interactions between phytochemicals. The multi-target therapeutic concept of phytotherapy. Curr Drug Targets 12:122-132

25. Ernster L (1967) DT diaphorase. In: Estabrook RW, Pullman ME (eds) Methods in enzymology, vol 10. Academic Press, New York, pp 309-317

26. Finn RD, McLaughlin LA, Ronseaux S, Rosewell I, Houston JB, Henderson CJ, Wolf CR (2008) Defining the in vivo role for cytochrome $b_{5}$ in cytochrome P450 function through the conditional hepatic deletion of microsomal cytochrome $b_{5}$. J Biol Chem 283:31385-31393

27. Fiske CH, Subbarow Y (1925) The colorimetric determination of phosphorous. J Biol Chem 66:375400

28. Gnanaraj C, Gothai S, Muniandy K, Thamaraiselvan R, Arulselvan P (2017) Toxicological and pharmacological use of anticancer compounds. In: Akhtar MS, Swamy MK (eds) Anticancer plants: 
clinical trials and nanotechnology, vol 3. Springer, Singapore, pp 203-231

29. Gu J, Cui H, Behr M, Zhang L, Zhang QY, Yang W, Hinson JA, Ding X (2005) In vivo mechanisms of tissue-selective drug toxicity: effects of liver-specific knockout of the NADPH-cytochrome P450 reductase gene on acetaminophen toxicity in kidney, lung, and nasal mucosa. Mol Pharmacol 67:623-630

30. Habig WH, Pabst MJ, Jakoby WB (1974) Glutathione S-transferases: the first enzymatic step in mercapturic acid formation. J Biol Chem 249:7130-7139

31. Hjertén S, Pan H (1983) Purification and characterization of two forms of a low affinity $\mathrm{Ca}^{2+}$-ATPase from erythrocyte membranes. Biochim Biophys Acta 728:281-288

32. Ighodaro OM, Akinloye OA (2017) First line defence antioxidants-superoxide dismutase (SOD), catalase (CAT) and glutathione peroxidase (GPX): their fundamental role in the entire antioxidant defence grid. Alexandria J Med 54:287-293

33. Iroanya OO, Adebesin OA, Okpuzor J (2014) Evaluation of the hepato and nephron-protective effect of a polyherbal mixture using wistar albino rats. J Clin Diagn Res 8:HC15-HC21

34. Ishak K, Baptista A, Bianchi L, Callea F, De Groote J, Gudat F, Denk H, Desmet V, Korb G, MacSween RN, Philips MJ, Portmann BG, Poulsen H, Scheuer PJ, Schmid M, Thaler H (1995) Histological grading and staging of chronic hepatitis. J Hepatol 22:696-699

35. Jeyadevi R, Ananth DA, Sivasudha T (2019) Hepatoprotective and antioxidant activity of Ipomoea staphylina Linn. Clin Phytosci 5:18

36. Ji L, Chauhan A, Brown WT, Chauhan V (2009) Increased activities of $\mathrm{Na}^{+} / \mathrm{K}^{+}$-ATPase and $\mathrm{Ca}^{2+} / \mathrm{Mg}^{2+}$-ATPase in the frontal cortex and cerebellum of autistic individuals. Life Sci $85: 788-793$

37. Jiang ZY, Hunt JV, Wolff SP (1992) Ferrous ion oxidation in the presence of xylenol orange for detection of lipid hydroperoxide in low density lipoprotein. Anal Biochem 202:384-389

38. Kale VP, Patel SG, Gunjal PS, Wakchaure SU, Sundar RS, Ranvir RK, Jain MR (2012) Effect of repeated freezing and thawing on 18 clinical chemistry analytes in rat serum. J Am Assoc Lab Anim Sci 51:475-478

39. Kaur P, Robin, Mehta RG, Arora S, Singh B (2018) Progression of conventional hepatic cell culture models to bioengineered HepG2 cells for evaluation of herbal bioactivities. Biotechnol Lett 40:881893

40. Kaur P, Robin, Mehta RG, Singh B, Arora S (2019) Development of aqueous-based multi-herbal combination using principal component analysis and its functional significance in HepG2 cells. BMC Complement Altern Med 19:18

41. Kaur R, Arora S (2013) Interactions of betulinic acid with xenobiotic metabolizing and antioxidative enzymes in DMBA-treated sprague dawley female rats. Free Radical Biol Med 65:131-142

42. Kim DO, Lee CY (2004) Comprehensive study on vitamin C equivalent antioxidant capacity (VCEAC) of various polyphenolics in scavenging a free radical and its structural relationship. Crit Rev Food Sci Nutr 44:253-273 
43. Kono Y (1978) Generation of superoxide radical during autoxidation of hydroxylamine and an assay for superoxide dismutase. Arch Biochem Biophys 186:189-195

44. Kullak-Ublick GA, Andrade RJ, Merz M, End P, Benesic A, Gerbes AL, Aithal GP (2017) Drug-induced liver injury: recent advances in diagnosis and risk assessment. Gut 66:1154-1164

45. Kuznetsov AV, Gnaiger E (2010) Laboratory protocol: Lactate dehydrogenase. Cytosolic marker enzyme. Mitochondr Physiol Network 08:18:1-8

46. Lam CTW, Chan PH, Lee PSC, Lau KM, Kong AYY, Gong AGW, Xu ML, Lam KYC, Dong TTX, Lin H, Tsim KWK (2016) Chemical and biological assessment of jujube (Ziziphus jujuba)-containing herbal decoctions: induction of erythropoietin expression in cultures. J Chromatogr B 1026:254-262

47. Lancaster EM, Hiatt JR, Zarrinpar A (2015) Acetaminophen hepatotoxicity: an updated review. Arch Toxicol 89:193-199

48. Liu YT, Chen YH, Uramaru N, Lin AH, Yang HT, Lii CK, Yao HT (2016) Soy isoflavones reduce acetaminophen-induced liver injury by inhibiting cytochrome P-450-mediated bioactivation and glutathione depletion and increasing urinary drug excretion in rats. J Funct Foods 26:135-143

49. Lobo V, Patil A, Phatak A, Chandra N (2010) Free radicals, antioxidants and functional foods: impact on human health. Pharmacogn Rev 4:118-126

50. Long F, Yang H, Xu Y, Hao H, Li P (2015) A strategy for the identification of combinatorial bioactive compounds contributing to the holistic effect of herbal medicines. Sci Rep 5:12361

51. Madkour FF, Abdel-Daim MM (2013) Hepatoprotective and antioxidant activity of Dunaliella salina in paracetamol-induced acute toxicity in rats. Indian J Pharm Sci 75:642-648

52. Mahmood ND, Mamat SS, Kamisan FH, Yahya F, Kamarolzaman MF, Nasir N, Mohtarrudin N, Tohid SF, Zakaria ZA (2014) Amelioration of paracetamol-induced hepatotoxicity in rat by the administration of methanol extract of Muntingia calabura L. leaves. Biomed Res Int 2014:695678. https://doi.org/10.1155/2014/695678

53. Mayuren C, Reddy VV, Priya SV, Devi VA (2010) Protective effect of Livactine against $\mathrm{CCl}_{4}$ and paracetamol induced hepatotoxicity in adult Wistar rats. N Am J Med Sci 2:491-495

54. McCrae JC, Morrison EE, Maclntyre IM, Dear JW, Webb DJ (2018) Long-term adverse effects of paracetamol - a review. Br J Clin Pharmacol 84:2218-2230

55. Mihara K, Sato R (1972) Partial purification of NADH-cytochrome b5 reductase from rabbit liver microsomes with detergents and its properties. J Biochem 71:725-735

56. Nithianantham K, Shyamala M, Chen Y, Latha LY, Jothy SL, Sasidharan S (2011) Hepatoprotective potential of Clitoria ternatea leaf extract against paracetamol induced damage in mice. Molecules 16:10134-10145

57. Ohnishi T, Suzuki T, Suzuki Y, Ozawa K (1982) A comparative study of plasma membrane $\mathrm{Mg}^{2+}$ ATPase activities in normal, regenerating and malignant cells. Biochim Biophys Acta 684:67-74

58. Olaleye MT, Akinmoladun AC, Ogunboye AA, Akindahunsi AA (2010) Antioxidant activity and hepatoprotective property of leaf extracts of Boerhaavia diffusa Linn against acetaminophen- 
induced liver damage in rats. Food Chem Toxicol 48:2200-2205

59. Omura T, Takasue S (1970) A new method for simultaneous purification of cytochrome b5 and NADPH-cytochrome $c$ reductase from rat liver microsomes. J Biochem 67:249-257

60. Ozer J, Ratner M, Shaw M, Bailey W, Schomaker S (2008) The current state of serum biomarkers of hepatotoxicity. Toxicology 245:194-205

61. Padma VV, Baskaran R, Divya S, Priya LB, Saranya S (2016) Modulatory effect of Tinospora cordifolia extract on Cd-induced oxidative stress in Wistar rats. Integr Med Res 5:48-55

62. Paglia DE, Valentine WN (1967) Studies on the quantitative and qualitative characterization of erythrocyte glutathione peroxidase. J Lab Clin Med 70:158-169

63. Parmar SR, Vashrambhai PH, Kalia K (2010) Hepatoprotective activity of some plants extract against paracetamol induced hepatotoxicity in rats. Journal of Herbal Medicine Toxicology 4:101-106

64. Paul S, Arya A, Gangwar A, Bhargava K, Ahmad Y (2016) Size restricted silymarin suspension evokes integrated adaptive response against acute hypoxia exposure in rat lung. Free Radical Biol Med 96:139-151

65. Rather MA, Bhat BA, Qurishi MA (2013) Multicomponent phytotherapeutic approach gaining momentum: is the "one drug to fit all". model breaking down? Phytomedicine 21:1-14

66. Sabir SM, Ahmad SD, Hamid A, Khan MQ, Athayde ML, Santos DB, Boligon AA, Rocha JBT (2012) Antioxidant and hepatoprotective activity of ethanolic extract of leaves of Solidago microglossa containing polyphenolic compounds. Food Chem 131:741-747

67. Sen S, Chakraborty R, Thangavel G, Logaiyan S (2015) Hepatoprotective and antioxidant activity of Karisalai Karpam, a polyherbal siddha formulation against acetaminophen-induced hepatic damage in rats. Anc Sci Life 34:198-202

68. Sharma V, Sharma A, Kansal L (2010) The effect of oral administration of Allium sativum extracts on lead nitrate induced toxicity in male mice. Food Chem Toxicol 48:928-936

69. Singh H, Prakash A, Kalia AN, Majeed AB (2016) Synergistic hepatoprotective potential of ethanolic extract of Solanum xanthocarpum and Juniperus communis against paracetamol and azithromycin induced liver injury in rats. J Tradit Complement Med 6:370-376

70. Smith PK, Krohn RI, Hermanson GT, Mallia AK, Gartner FH, Provenzano MD, Fujimoto EK, Goeke NM, Olson BJ, Klenk DC (1985) Measurement of protein using bicinchoninic acid. Anal Biochem 150:7685

71. Stine JG, Chalasani NP (2017) Drug Hepatotoxicity: Environmental Factors. Clin Liver Dis 21:103113

72. Tatiya AU, Surana SJ, Sutar MP, Gamit NH (2012) Hepatoprotective effect of poly herbal formulation against various hepatotoxic agents in rats. Pharmacogn Res 4:50-56

73. Tittarelli R, Pellegrini M, Scarpellini MG, Marinelli E, Bruti V, di Luca NM, Busardò FP, Zaami S (2017) Hepatotoxicity of paracetamol and related fatalities. Eur Rev Med Pharmacol Sci 21:95-101 
74. Tresserra-Rimbau A, Arranz S, Vallverdu-Queralt A (2017) New insights into the benefits of polyphenols in chronic diseases. Oxid Med Cell Longevity 2017:1432071

75. Uboh FE, Okon IE, Ekong MB (2010) Effect of aqueous extract of Psidium guajava leaves on liver enzymes, histological integrity and haematological indices in rats. Gastroenterol Res 3:32-38

76. United States Food and Drug Administration (FDA) (2015) Acetaminophen.

https://www.accessdata.fda.gov/drugsatfda_docs/label/2015/204767s000lbl.pdf

77. Williams DA (2013) Drug metabolism. In: Lemke TL, Williams DA, Roche VF, Zito SW (eds) Foye's Principles of Medicinal Chemistry, 7th edn. Wolters Kluwer Health Adis (ESP), pp 106-190

78. World Health Organization (WHO) (2019) WHO Model List of Essential Medicines - 21 st list (No. World Health Organization, Geneva, WHO/MVP/EMP/IAU. /2019.06

79. Yoon E, Babar A, Choudhary M, Kutner M, Pyrsopoulos N (2016) Acetaminophen-induced hepatotoxicity: a comprehensive update. J Clin Transl Hepatol 4:131-142

\section{Figures}

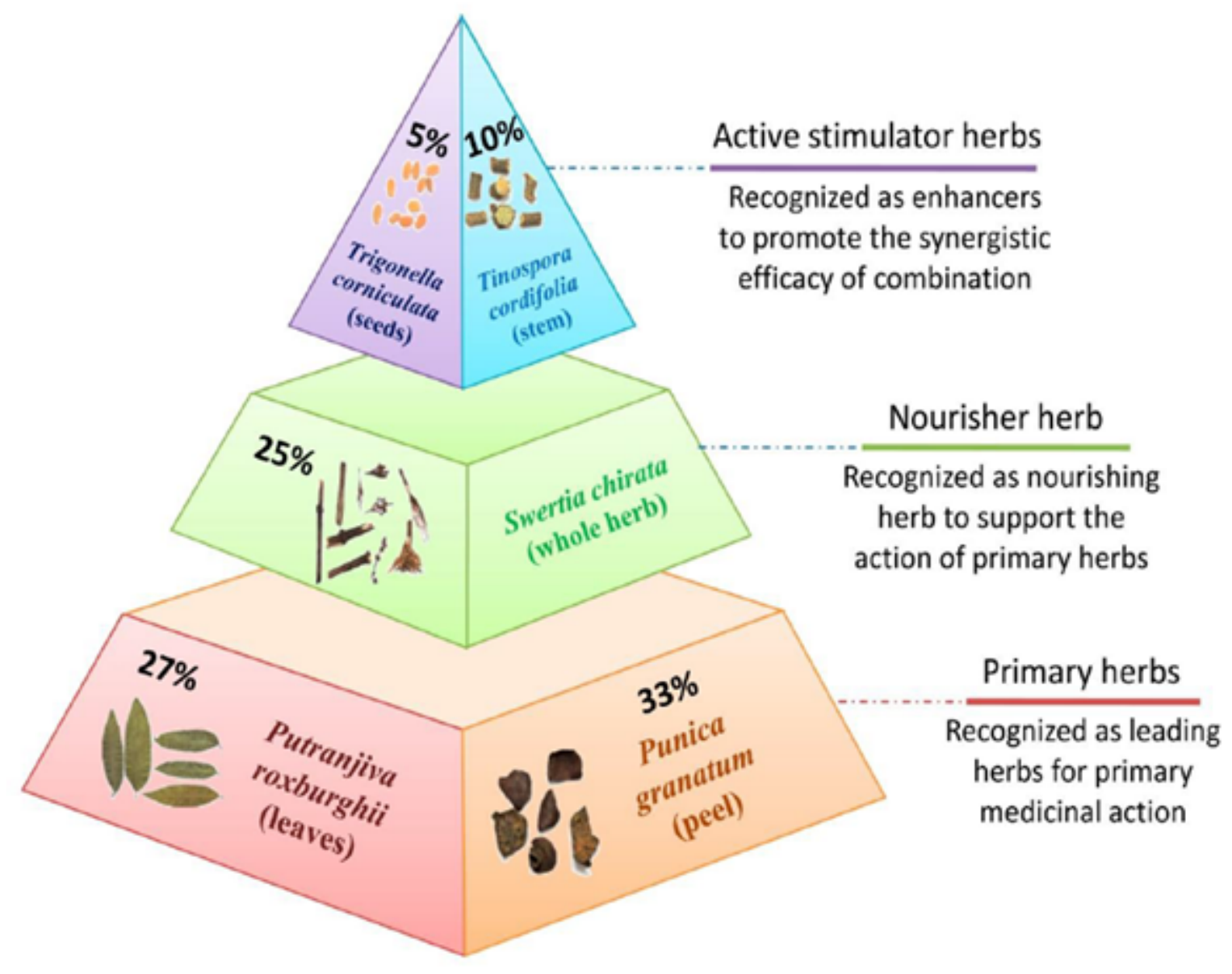

Figure 1 Development of multi-herbal combination MHC

\section{Figure 1}


Caption found in figure.

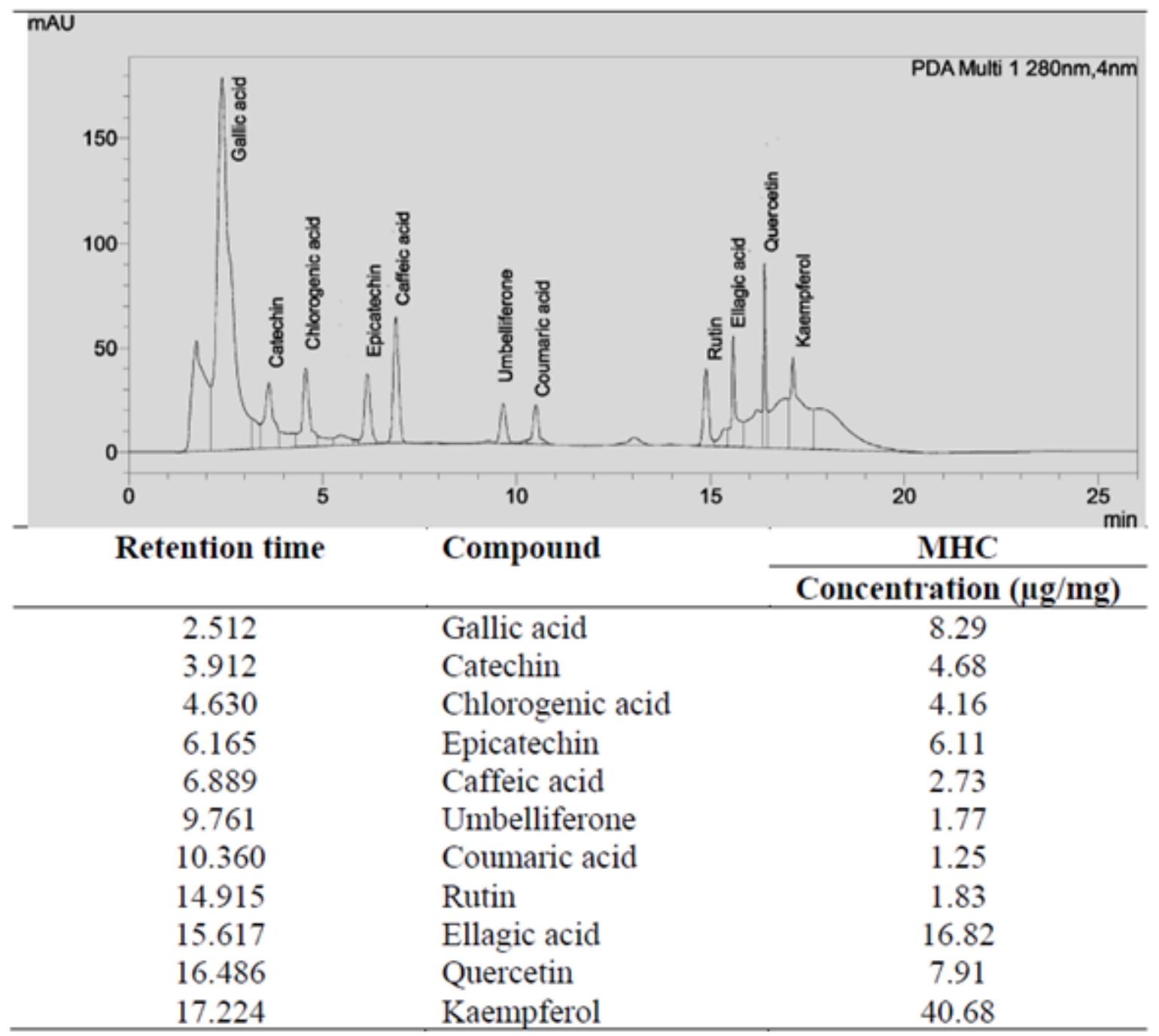

Figure 2 HPLC-PDA chromatogram of multi-herbal combination (MHC)

Figure 2

Caption found in figure. 


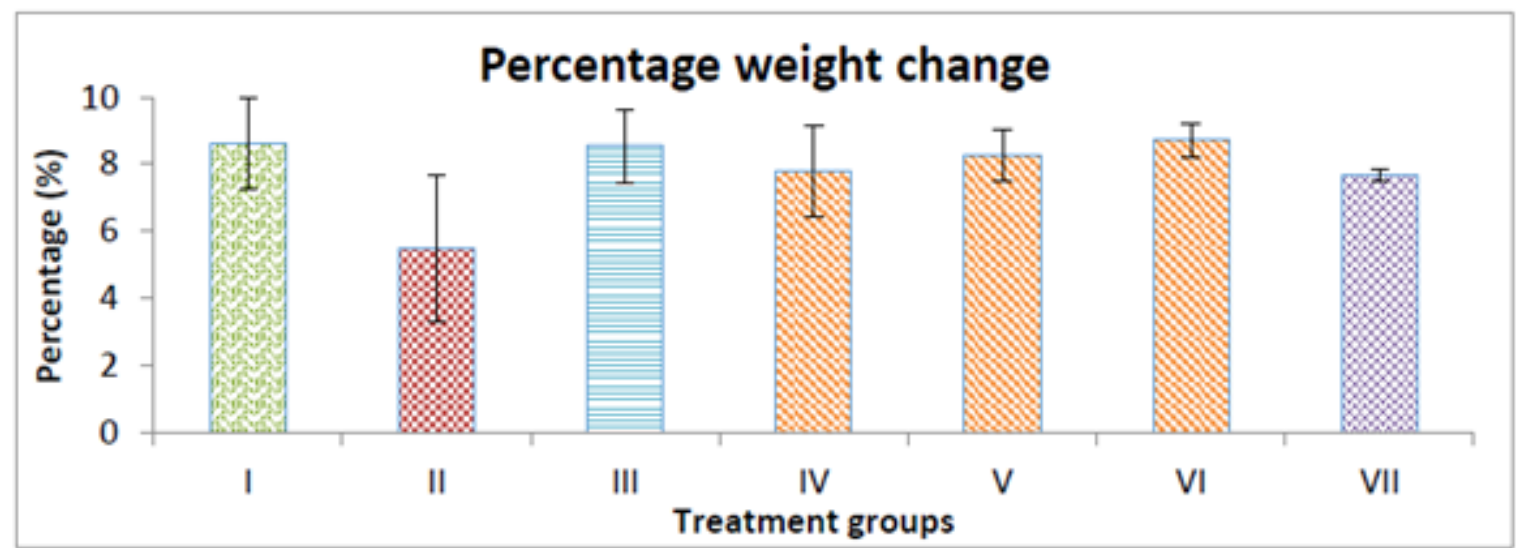

Group I: Normal control; Group II: Paracetamol (3 g/kg bw); Group III: MHC (200 mg/kg bw) per se; Group IV: MHC (50 mg/kg bw) + Paracetamol; Group V: MHC (100 mg/kg bw) + Paracetamol; Group VI: MHC $(200 \mathrm{mg} / \mathrm{kg}$ bw) + Paracetamol; Group VII: Silymarin $(50 \mathrm{mg} / \mathrm{kg}$ bw $)+$ Paracetamol; Animals in each group $(n=6)$

Figure 3 Percentage change in body weight of animals in different treatment groups

\section{Figure 3}

Caption found in figure. 

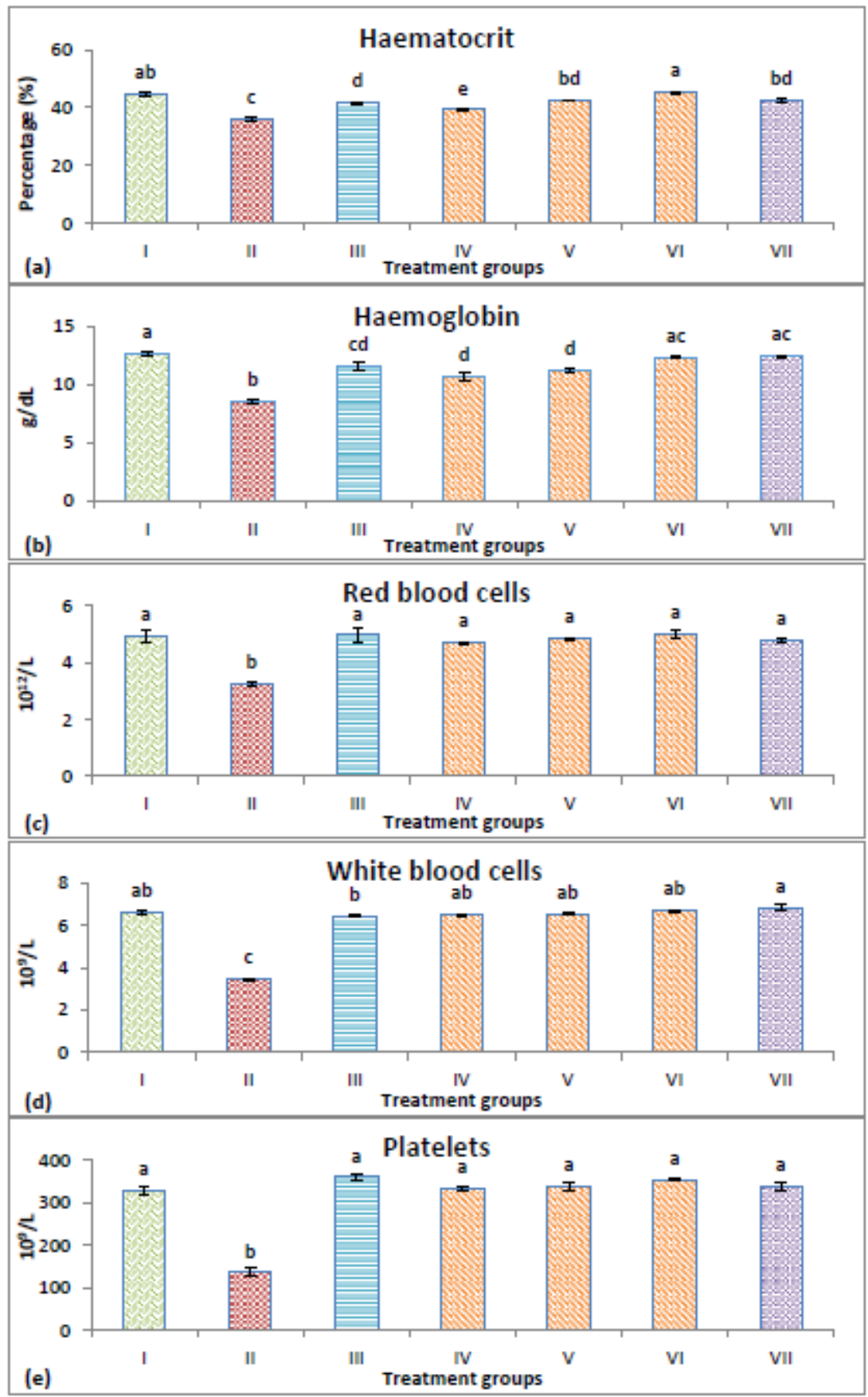

(e)

Group I: Normal control: Group II: Paracetamol ( $3 \mathrm{~g} / \mathrm{kg}$ bw)-Group III: MHC (200 mg/kg bw) per se: Group IV: MHC (50 mg/kg bw) + Paracetamol; Group V: MHC (100 mg/kg bw) + Paracotamol; Group V: MHC $(200 \mathrm{mg} / \mathrm{kg}$ bw) + Paracetamol; Group VII: Silymarin $(50 \mathrm{mg} / \mathrm{kg}$ bw + Paracetamol; Treatment groups with different lowercase ietter(s) differ signifficantly at $p \leq 0.05$ (Tukey's HSD test); Animais in each group $(n=6)$

Figure 4 Modulatory effect of MHC pre-treatment on paracetamol-mediated alterations in haematological indices

Figure 4

Caption found in figure. 

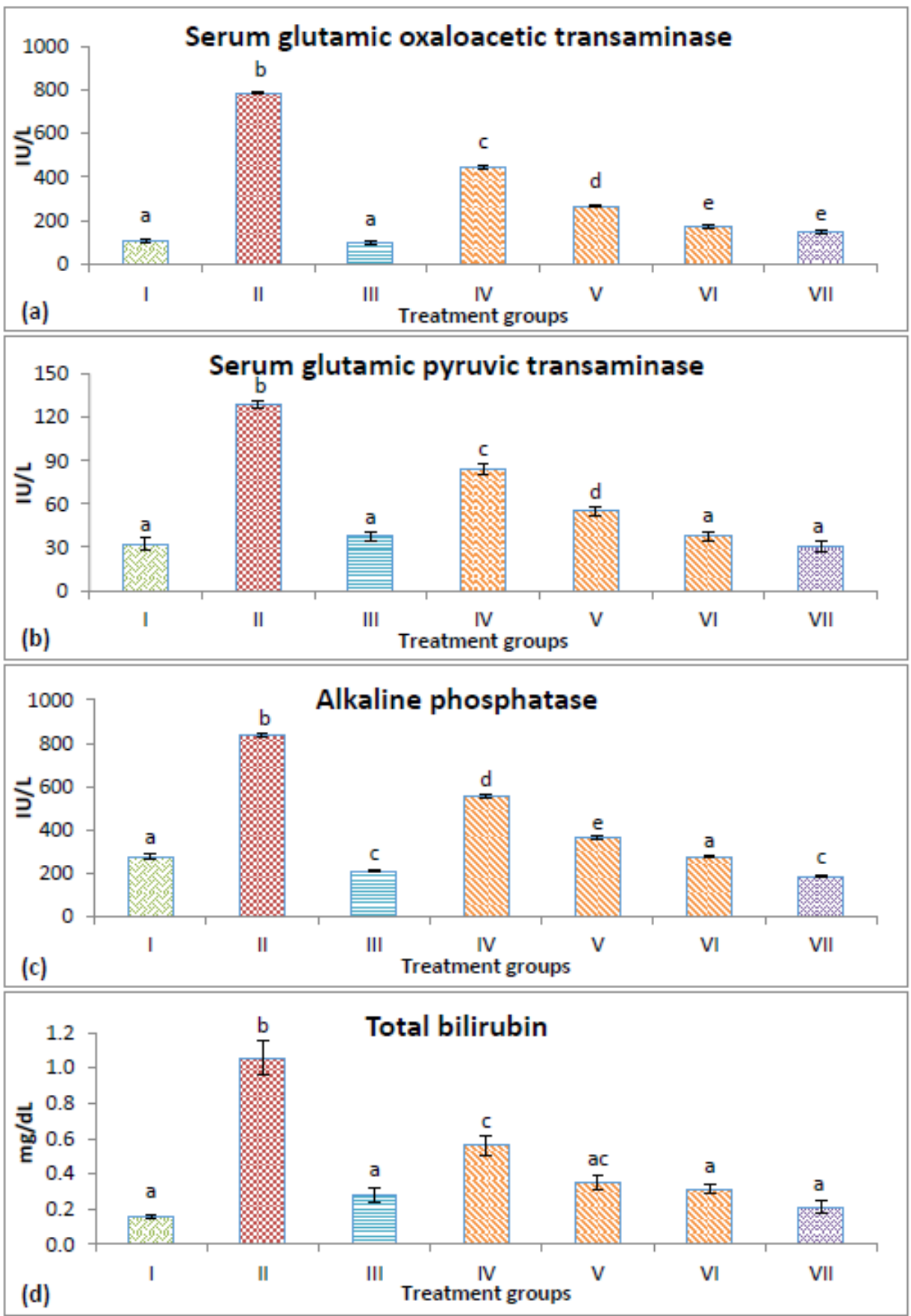

Group I: Normal control; Group II: Paracetamol (3 g/kg bw): Group III: MHC (200 mg/kg bw) per se: Group IV: MHC (50 mg/kg bw) + Paracetamol; Group V: MHC (100 mg/kg bw) + Paracetamol; Group VI: MHC $(200 \mathrm{mg} / \mathrm{kg}$ bw) + Paracetamol; Group VII: Silymarin $(50 \mathrm{mg} / \mathrm{kg}$ bw) + Paracetamol; Treatment groups with different lowercase letter(s) differ significantly at $p \leq 0.05$ (Tukey's HSD test); Animals in each group $(n=6)$

Figure 5 Modulatory effect of MHC pre-treatment on paracetamol mediated alterations on serum liver function biomarkers

\section{Figure 5}

Caption found in figure. 

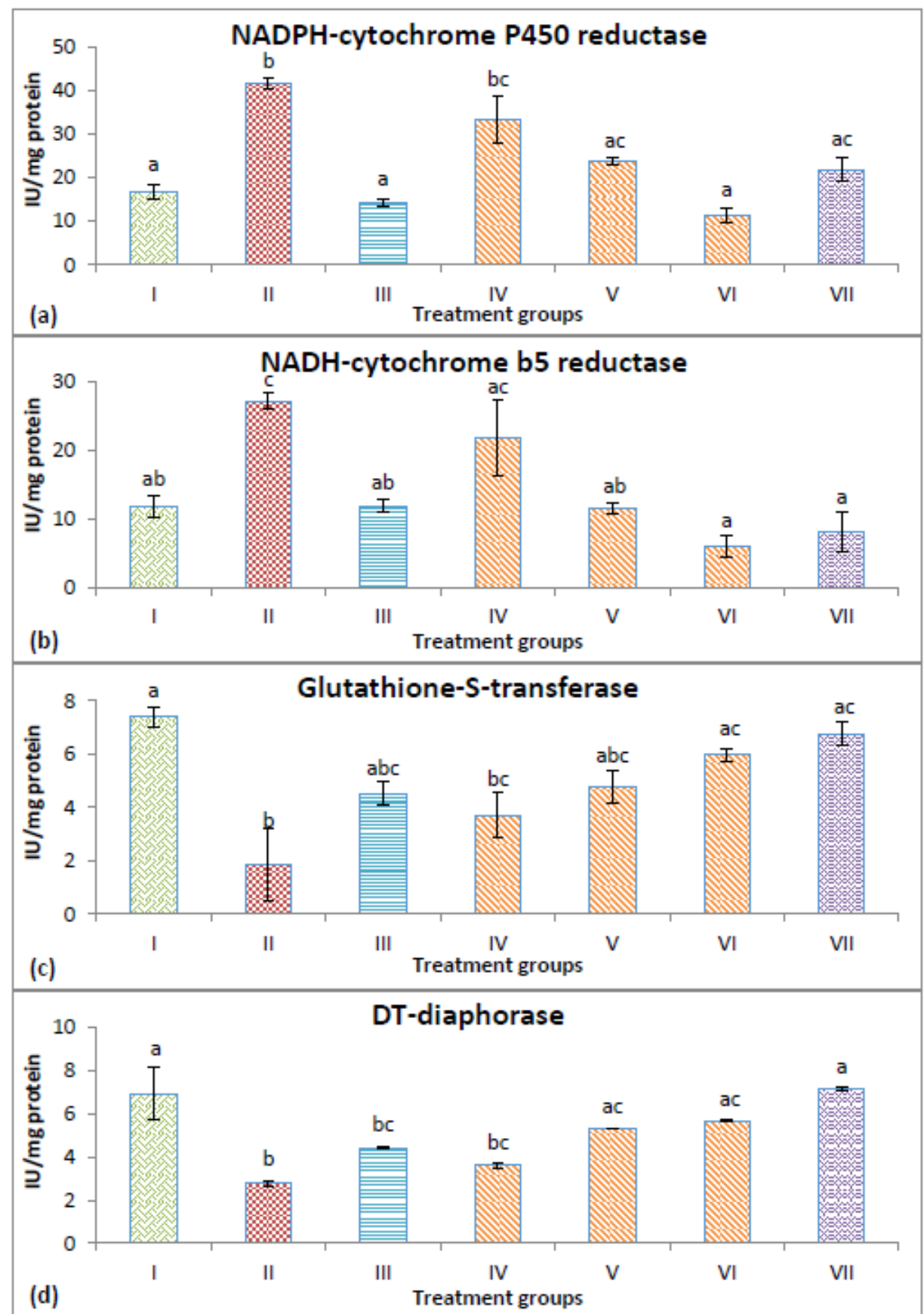

Group I: Normal control; Group II: Paracetamol (3 g/kg bw); Group III: MHC (200 mg/kg bw) per se; Group IV: $M H C(50 \mathrm{mg} / \mathrm{kg} \mathrm{bw})+$ Paracetamol: Group V: MHC (100 mg/kg bw) + Paracetamol; Group VT: MHC $(200 \mathrm{mg} / \mathrm{kg} \mathrm{bw})+$ Paracetamol; Group VII: Silymarin $(50 \mathrm{mg} / \mathrm{kg} \mathrm{bw})+$ Paracetamol; Treatment groups with different lowercase letter(s) differ significantly at $p \leq 0.05$ (Tukey's HSD test); Animals in each group $(n=6)$

Figure 6 Modulatory effect of MHC pre-treatment on paracetamol-mediated alterations in phase-I ( $a$ and b) and phase-II (c and d) reaction enzymes

\section{Figure 6}

Caption found in figure. 


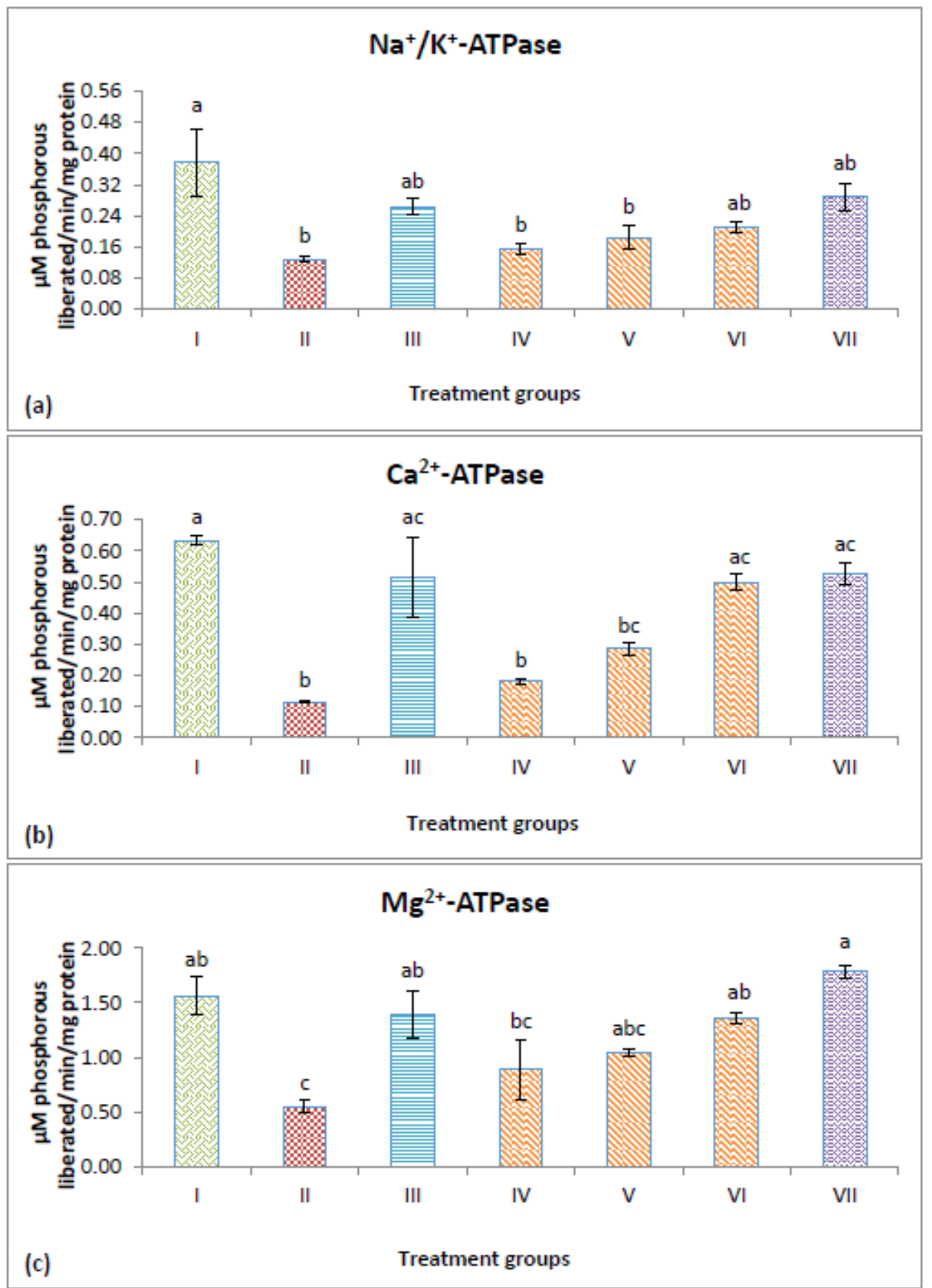

Group I: Normal control; Group II: Paracetamol (3 g/kg bw); Group III: MHC (200 mg/kg bw) per se; Group IV: MHC (50 mg/kg bw) + Paracetamol; Group V: MHC (100 mg/kg bw) + Paracetamol; Group VI: MHC (200 mg/kg bw) + Paracetamol; Group VII: Silymarin $(50 \mathrm{mg} / \mathrm{kg} \mathrm{bw})+$ Paracetamol; Treatment groups with different lowercase letter(s) differ significantly at $p \leq 0.05$ (Tukey's HSD test); Animals in each group $(n=6)$

Figure 7 Modulatory effect of MHC pre-treatment on paracetamol mediated alterations in membrane bound enzymes

Figure 7

Caption found in figure. 

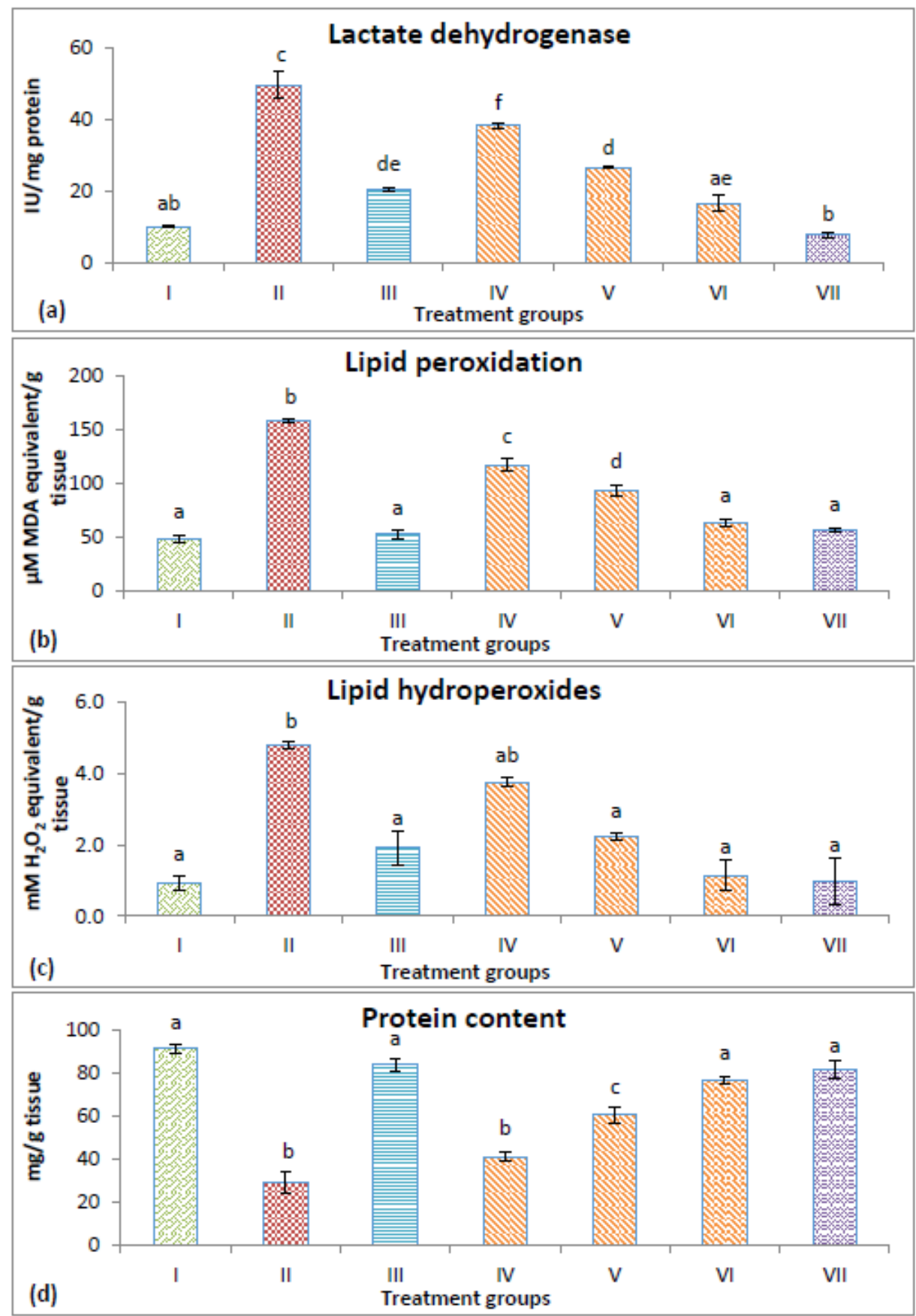

Group I: Normal control; Group II: Paracetamol (3 g/kg bw); Group III: MHC (200 mg/kg bw) per se; Group IV: MHC (50 mg/kg bw) + Paracetamol; Group V: MHC (100 mg/kg bw) + Paracetamol; Group V: MHC (200 mg/kg bw) + Paracetamol; Group VII: Silymarin (50 mg/kg bw) + Paracetamol; Treatment groups with different lowercase letter(s) differ significantly at $p \leq 0.05$ (Tukey's HSD test); Animals in each group $(n=6)$

Figure 8 Modulatory effect of MHC pre-treatment on paracetamol-mediated alterations in oxidant biomarkers

\section{Figure 8}

Caption found in figure. 

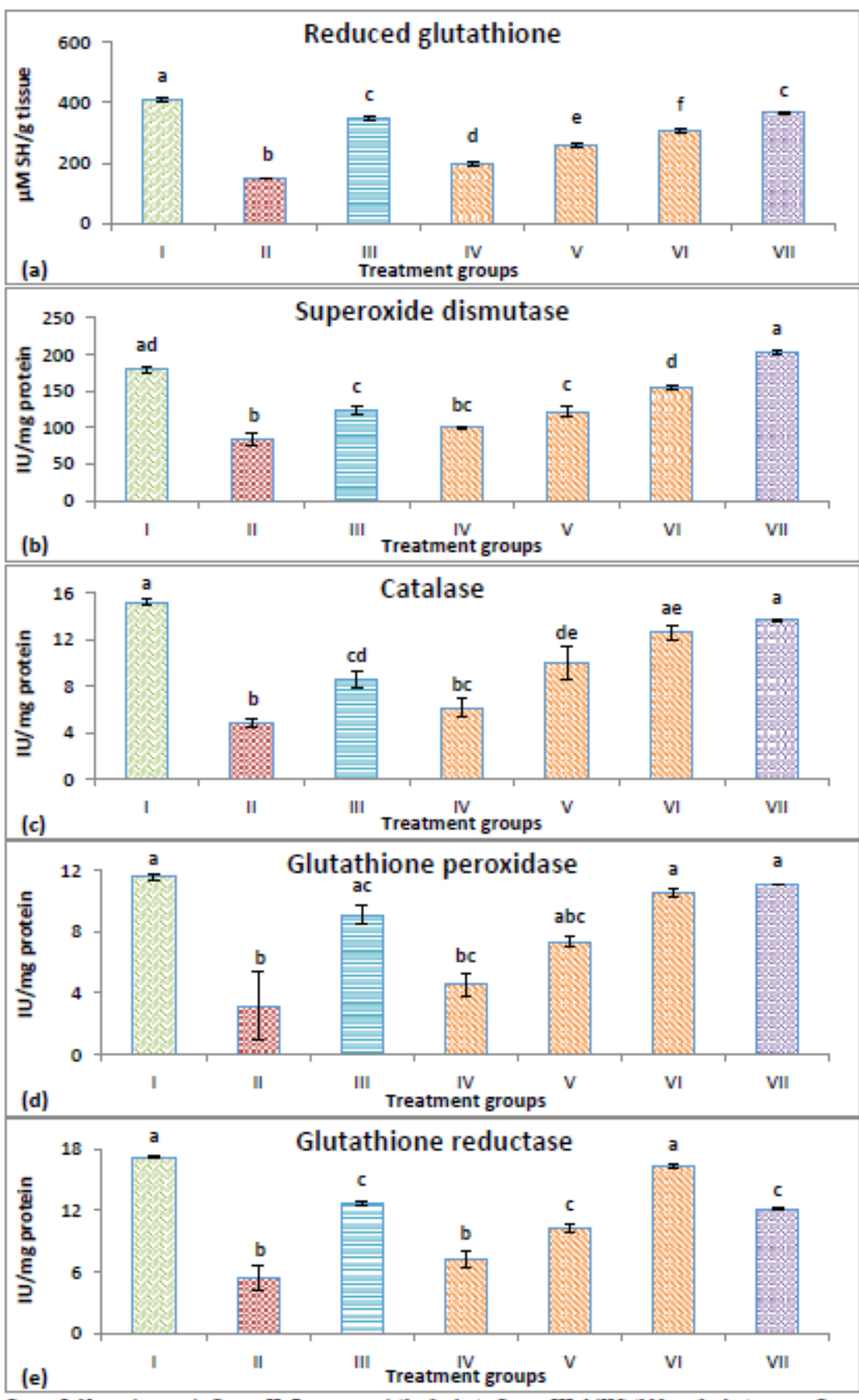

Group I: Normal control; Group II: Paracetamol (3 g/kg bw); Group III: $\mathrm{MHC}(200 \mathrm{mg} / \mathrm{kg}$ bw) per se; Group IV: MHC (50 mg/kg bw) + Paracetamol; Group V: MHC $(100 \mathrm{mg} / \mathrm{kg}$ bw) + Paracetamol; Group VI: MHC $(200 \mathrm{mg} / \mathrm{kg}$ bw) + Paracetamol; Group VII: Silymarin $(50 \mathrm{mg} / \mathrm{kg}$ bw) + Paracetamol; Treatment groups with different lowercase ietter(s) differ signifficantly at $p \leq 0.05$ (Tukey's HSD test); Animals in oach group $(n=6)$

Figure 9 Modulatory effect of $\mathrm{MHC}$ pre-treatment on paracetamol mediated alterations in antioxidant biomarkers

\section{Figure 9}

Caption found in figure. 


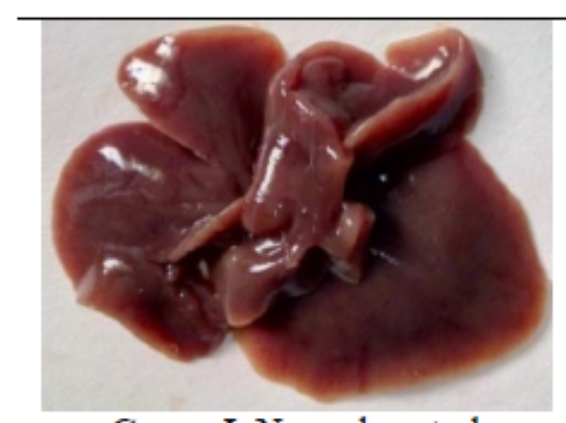

Group I: Normal control

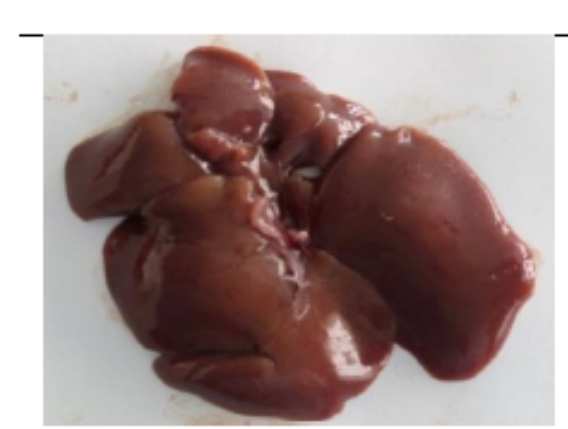

Group III: MHC

(200 mg/kg bw) per se

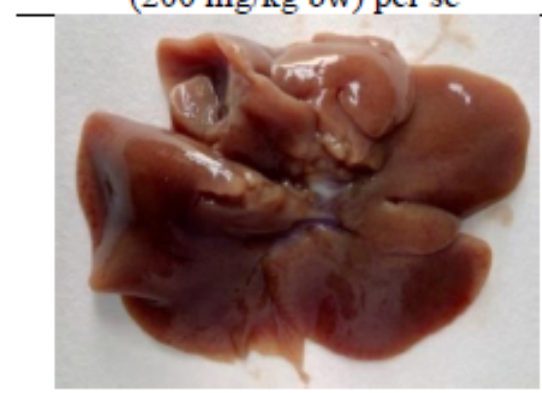

Group V: MHC

$(100 \mathrm{mg} / \mathrm{kg} \mathrm{bw})+$ Paracetamol

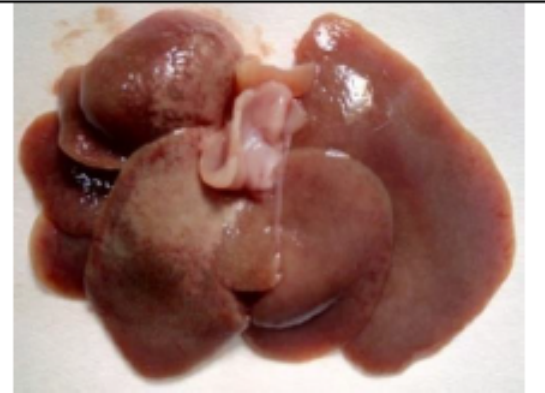

Group II: Paracetamol

$(3 \mathrm{~g} / \mathrm{kg} \mathrm{bw})$

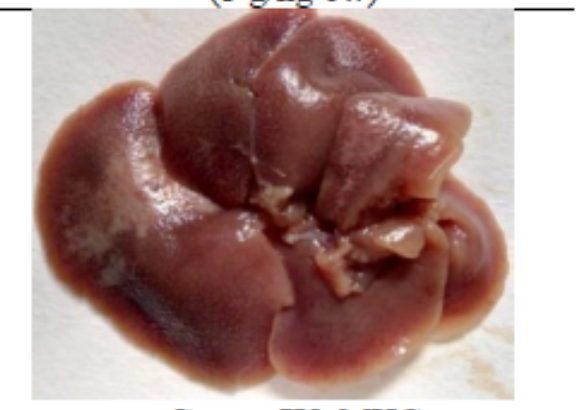

Group IV: $\mathrm{MHC}$

$(50 \mathrm{mg} / \mathrm{kg} \mathrm{bw})+$ Paracetamol

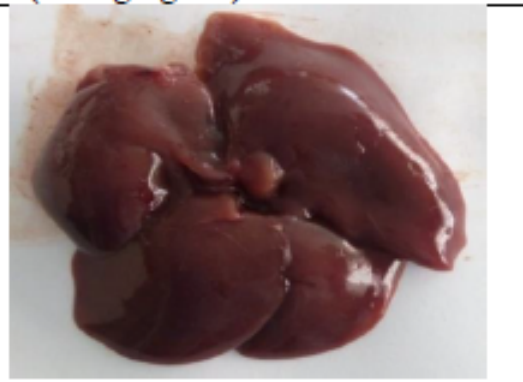

Group VI: MHC

$(200 \mathrm{mg} / \mathrm{kg} \mathrm{bw})+$ Paracetamol

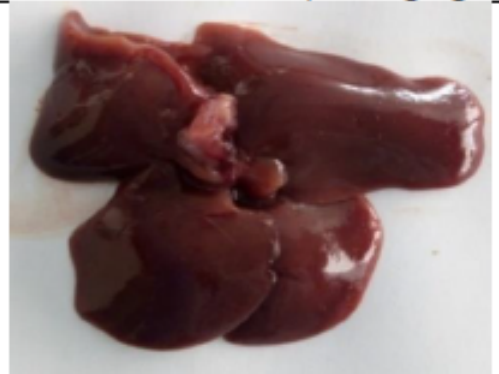

Group VII: Silymarin

$(50 \mathrm{mg} / \mathrm{kg}$ bw $)+$ Paracetamol

Figure 10 Gross morphological appearance of animal livers in different treatment groups

\section{Figure 10}

Caption found in figure. 


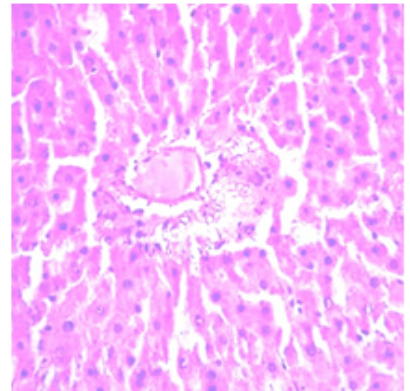

Group I: Normal hepatocytes

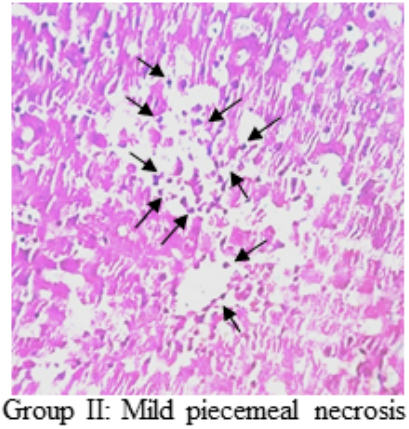

Group II: Mild piecemeal necrosis

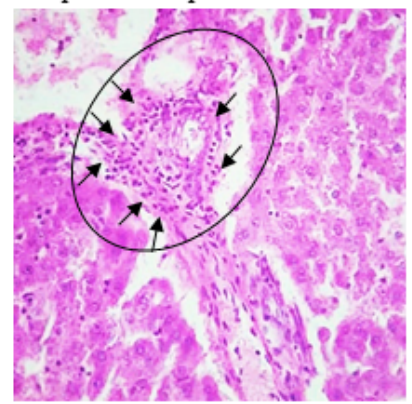

Group V: Portal triad inflammation

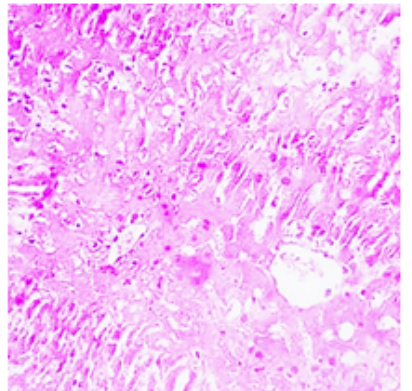

$$
\text { Group II: Massive necrosis }
$$

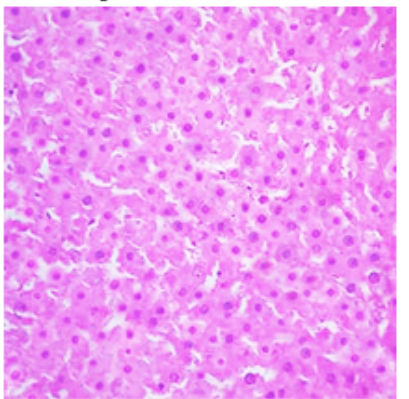

Group III: No sign of degeneration

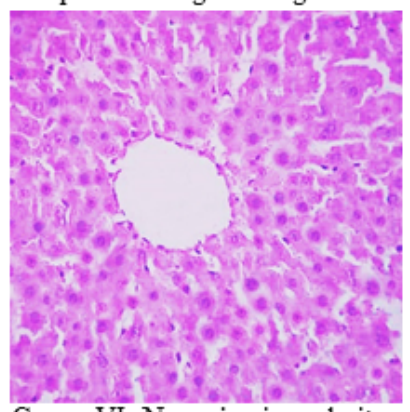

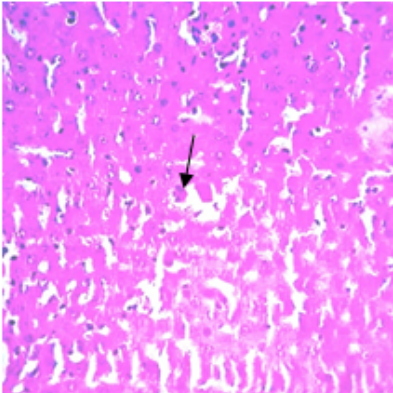
Group II: Apoptosis

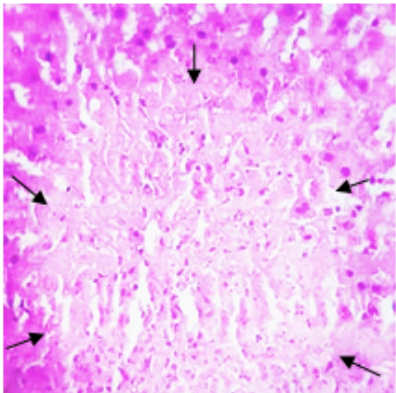

Group IV: Coagulative necrosis

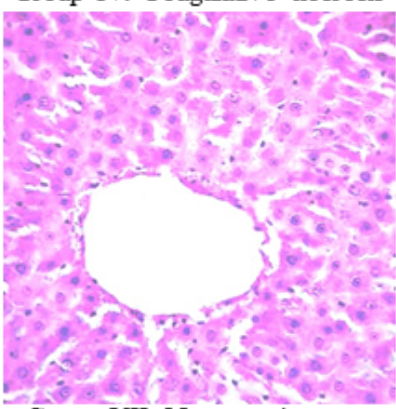

Group VII: No necrotic zone

Figure 11 Microscopical examination of Hematoxylin and Eosin stained sections of liver tissues (original magnification: 400×)

\section{Figure 11}

Caption found in figure. 


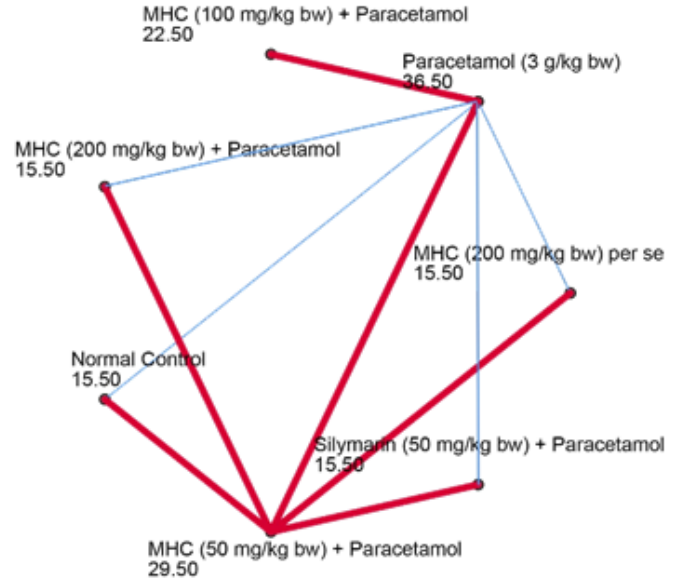

(a) Periportal or periseptal interface hepatitis (piecemeal necrosis)

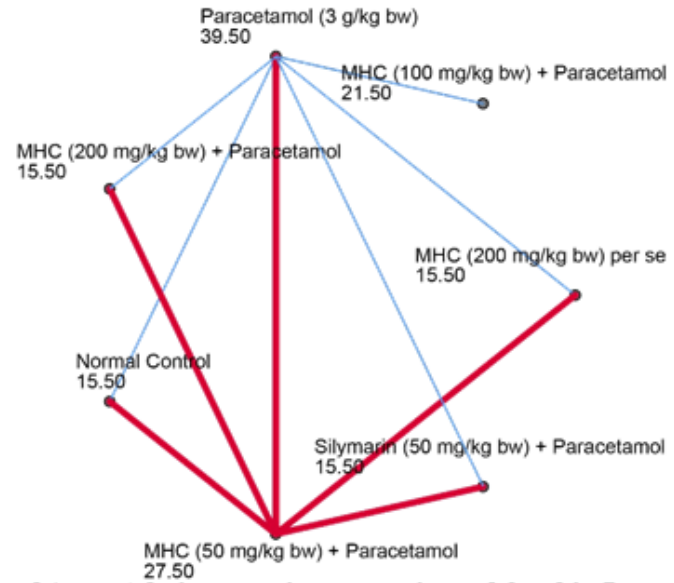

(c) Focal (spotty) lytic necrosis, apoptosis, and focal inflammation

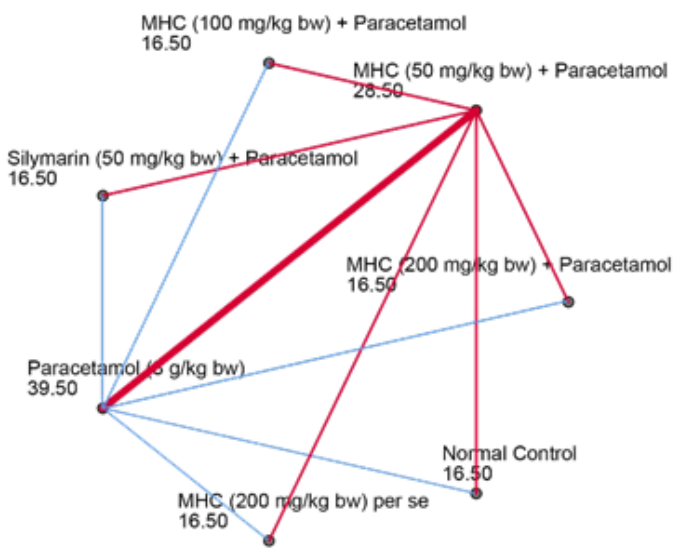

(b) Confluent necrosis

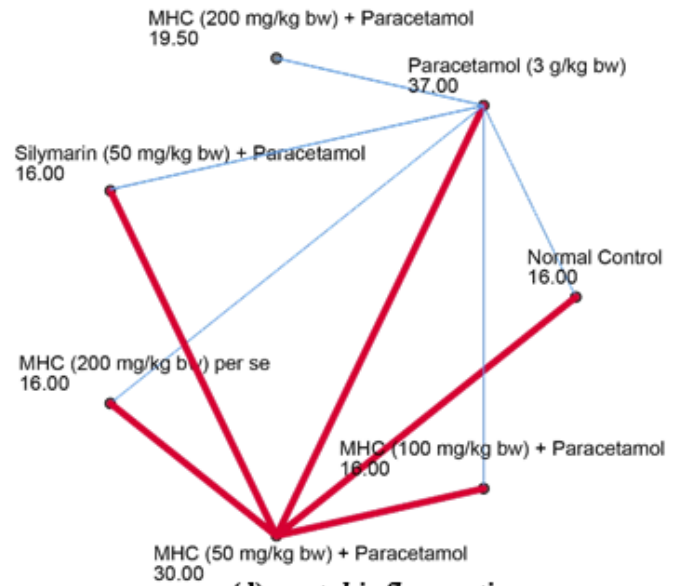

(d) portal inflammation

Figure 12 Dunn-Bonferroni pairwise comparisons with each node showing sample average rank of group [Blue lines indicate statistically significant differences at $p \leq 0.05$ ]

\section{Figure 12}

Caption found in figure. 


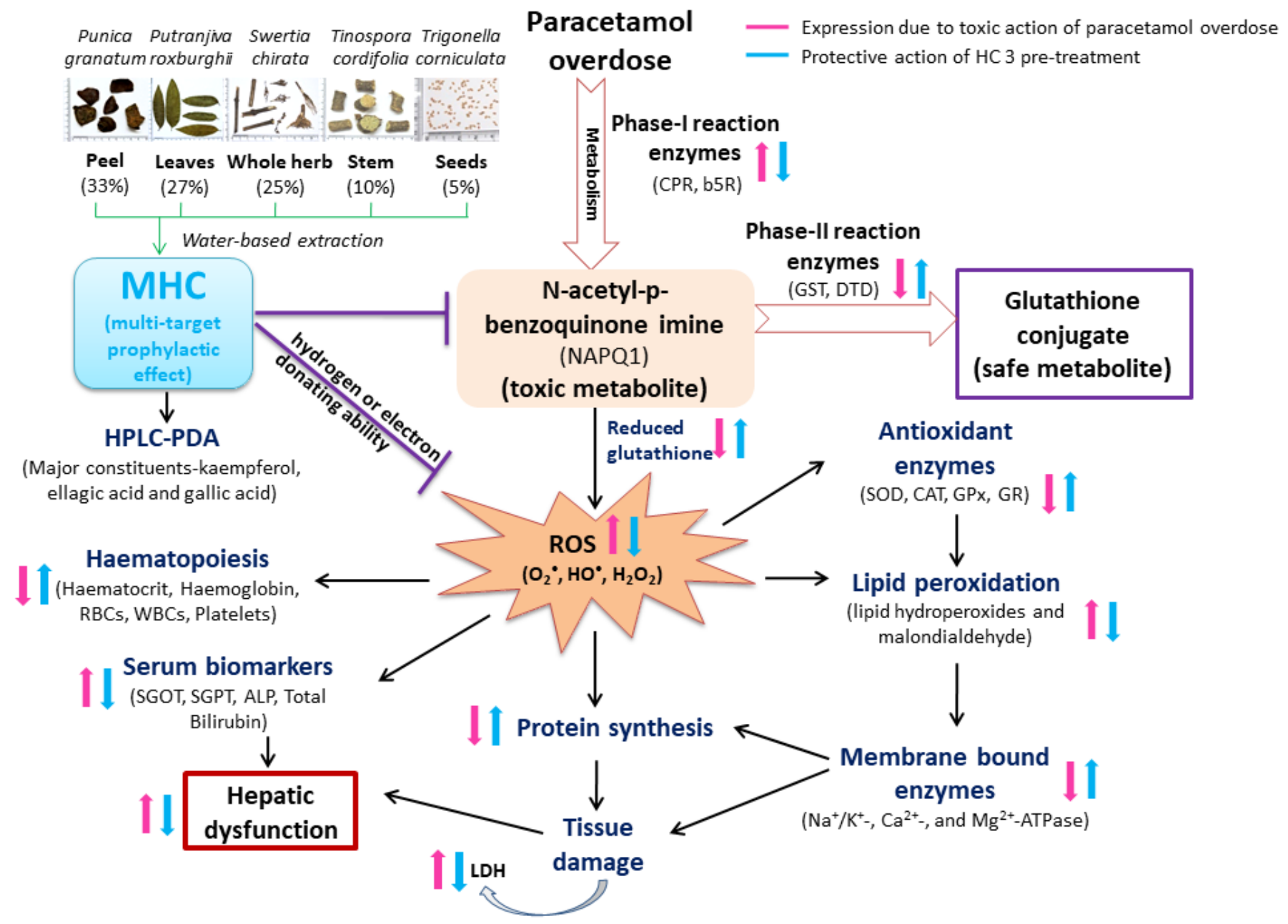

Figure 13 Modulatory effect of MHC against paracetamol induced acute hepatotoxicity in female Wistar rats

Figure 13

Caption found in figure.

\section{Supplementary Files}

This is a list of supplementary files associated with this preprint. Click to download.

- SupplementaryTables.docx 